\title{
A review of the French Protonemura (Plecoptera, Nemouridae)
}

\author{
G. Vinçon ${ }^{1 *}$, C. Ravizza ${ }^{2}$ \\ 174 rue du Drac, F-38000 Grenoble, France. \\ 2 Largo O. Murani 4, I-20133 Milano, Italy.
}

\begin{abstract}
In this revision of the 25 French Protonemura, two new taxa are described : P. zhiltzovae sp. n. and P. ausonia padana ssp. n. Moreover, P. spinulosa (Navás 1921) is restored to the species level. Affinities, etymology, ecology and distribution are commented on for each species. Identification keys and drawings are given for males and females. Finally, Protonemura distributions within the main French mountainous massifs are discussed.
\end{abstract}

Keywords : Plecoptera, Protonemura, France, Corsica.

\section{Introduction}

The family Nemouridae is represented in Europe by only four genera, all of them present in France. Newman established the family Nemouridae in 1853 . He included in it all the families that at present are comprised in the super family Nemouridea (Zwick 1973). In the $19^{\text {th }}$ century, the first descriptions of European Protonemura species, were assigned to the genus $\mathrm{Ne}$ moura (Pictet 1835, 1841, Morton 1894). Few years after, Kempny (1898) and Ris (1902) considered Protonemura as a subgenus of Nemoura. In the $20^{\text {th }}$ century, Klapalek (1905) separated the Nemouridae into four families : Capniidae, Leuctridae, Nemouridae and Taeniopterygidae. Afterwards, Mosely (1930), Kimmins (1940), Illies (1955), Aubert (1959), and the following authors considered Protonemura as an autonomous genus. Regarding the French Protonemura, there have been several main compilations : the monograph of the French stoneflies by Despax (1951) that provides detailed descriptions and illustrations for 13 species of Protonemura; the works by Aubert in the main French mountainous regions : Massif Central (1963a, 1963d), Vosges (1963b) and French Alps (1986); the

\footnotetext{
* Corresponding author : E-mail: Vincon@kls-logistic.fr
}

contributions by Berthélemy in the Pyrenees (1960, 1963, 1966, 1981) and Massif Central (Berthélemy 1965, Berthélemy \& Laur 1975). For this study, the review of our French Protonemura material collected during the last twenty years allows us to identify two new taxa: P. zhiltzovae sp. n. occurring in the Pyrenees and $P$. ausonia padana ssp. $\mathrm{n}$. inhabiting the Western Alps and Northern Apennines. At the present time the genus Protonemura is represented in France by 25 species.

\section{Material and methods}

The material of Protonemura used in this study belongs to the private collection of G. Vinçon. The specimens were collected in the main French mountain and upland regions (Fig. 11). The number of collecting sites are : Alps 175, Pyrenees 137, Massif Central 40, Corsica 28, Jura 22, Brittany 5, Vosges 2 and Normandy 1 . In each collecting place, the sampling took about an hour. The captures were made first with a Japanese umbrella in the close surrounding of the watercourse and afterwards searching under the stones and in the stream bank vegetation. Most of the sampling sites were visited several times a year, in spring, summer, autumn and sometimes in winter. The material is preserved in alcohol (70\%). The identifications are always 
based on adult specimens. Moreover to complete our study, specimens were borrowed in few European collections : Aubert, Berthélemy, Despax, Fochetti and Ravizza. Original drawings are made by G. Vinçon, using a camera lucida mounted on a stereomicroscope. Some drawings are reproduced from the literature and modified by us afterwards, as indicated in the legend of the figures. In the description of the male and female terminalia we use the terminology proposed by Baumann (1975). The morphological structure of the adults is illustrated in Fig. 1. Type specimens are deposited in the Zoological Museum of Lausanne, Switzerland. Other specimens are hold by G. Vinçon (Grenoble, France) and C. Ravizza (Milano, Italy).

\section{Species list}

For each species, we give first the reference of the original description, and then the synonyms and works dealing with its taxonomy. Afterwards we present the results of our own collections in the different French mountainous regions (Alps, Jura, Vosges, Brittany, Massif Central, Pyrenees and Corsica) (Fig. 11). The complete list of the collecting sites is given in the Atlas of the French Stoneflies (Le Doare \& Vinçon, under realisation) and also could be asked to the authors. The list is completed by data on type locality, etymology, affinities, ecology and geographical distribution. The species are considered according to a modification of the groups proposed by Rauser (1962).

\section{tuberculata group}

Group characterized by the strong prominent ventral tubercle on the epiproct.

Protonemura culmenis Zwick \& Vinçon, 1993 (Fig. 2 a-e) (Fig. 12)

Protonemura culmenis Zwick \& Vinçon, 1993 : $52-54$ fig. 4.

Material : Pyrenees : Ariège, Andorra (Zwick \& Vinçon 1993). Type locality : Arinsal (Coma Pedrosa brook below the Coma Pedrosa lake, $2700 \mathrm{~m}$ a.s.1.), Sègre high valley, Andorra, Pyrenees. Etymology : From Latin culmen $=$ summit, because it lives only at high altitude. Affinities : Closely related to $P$. tuberculata, from which the male is easy to separate by the shape of the epiproct and paraprocts. Nevertheless, the female is more similar and may be separated by the presence of a small pigmented pregenital plate at the end of sternite VII (Fig. 2e). Ecology : This rheophilic, stenothermous cold-water species only occurs in very high altitude springs and brooks (2000-2700 m). The- refore, it is the most strongly orophilic stonefly in the Pyrenees. Adults emerge in summer (VII-VIII). Distribution : This micro-endemic species is only known from a small part of the Eastern Pyrenees : Ariège (France) and Andorra (Fig. 12).

$\mathrm{f}-\mathrm{j})$

Protonemura tuberculata (Despax, 1929) (Fig. 2

Nemoura (Protonemura) tuberculata Despax, $1929: 85$ fig. 5-10.

Material : Pyrenees : Pyrénées-Orientales, Aude, Ariège, Pyrénées-Atlantiques. Type locality : French Pyrenees. Etymology : From Latin tuber = tubercle, because it is provided with a strong tubercle on the inferior face of the male epiproct. Affinities : it is clearly separated from all the other species belonging to the tuberculata group. Ecology : strongly orophilic, stenothermous cold-water species, restricted to the subalpine and alpine zones (1300-2550 m) or in few cold springs of the montane zone. Its highest site in the Pyrenees is in Andorra (Arinsal, Coma Pedrosa, 2550 m, 6 ơ, 5 \%, 14-VII-86). Distribution : Pyrenean endemic restricted to the higher part of the chain, in both Spain and France.

\section{corsicana group}

Group characterized by the well-developed terminal filament of the epiproct.

Protonemura ausonia padana ssp. n. (Fig. 2 k-p) (Fig. 13)

\section{Protonemura ausonia - Vinçon, 1996: 62, 69.}

Type locality: Italy: Piemont, Fenestrelle, Chisone Valley, brook between Usseaux and Balboutet, 1500 $\mathrm{m}, 1-\mathrm{XI}-99$. The holotype and $30^{\circ}, 4$ \& paratypes are deposited in the Zoological Museum of Lausanne, Switzerland. Other paratypes, same date and locality, 5 $\mathrm{O}^{7}, 5$ o (Vinçon collection). Other material : France : Alpes-Maritimes : Roya Valley: Tende pass, 1200 m, 1 \%, 18-X-87; Caramagne River, 1300 m, 1 ơ, 1 ㅇ, 27-IX-88; Lavenza trib., Notre-Dame-des-Fontaines, 850 m, 1 ㅇ, 28-IX88. Vésubie Valley: La-Bollène-Vésubie, 1100 m, 1 O’, 28IX-88. Italy : Graian Alps : Susa Valley: Dora Riparia trib., Sestrière, 2000 m, 1 O', 28-IX-02; S. Susa: Fontana della Batteria, 1310 m, 2 o", 8 \%, 23-X-00; Fontana della Gelassetta, 1200 m, 1 ơ, 7 ㅇ, 23-X-00. Cottian Alps : Sangone Valley, Coazze, Prietto, 900 m, 5 ơ, 1 ㅇ, 26-X-02 (Delmastro leg.). Chisone Valley: Finestre Pass, spring, 1800 m, 3 o', 3 o, 28IX-02; Perosa-Argentina, Meano, Selvagio, 1200 m, 4 O’, 29IX-02; W. San Germano Chisone, Ruata, 1 o', 1 ㅇ, 26-XII94. Germanasca Valley, Perrero, Chiotti, 1400 m, 1 ơ, 2 우, 28-IX-02. Pellice Valley, S. Bobbio Pellice, Comba di Car- 

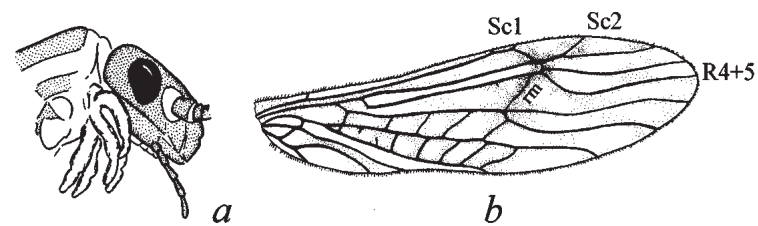

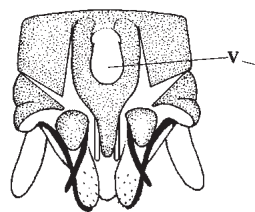

c
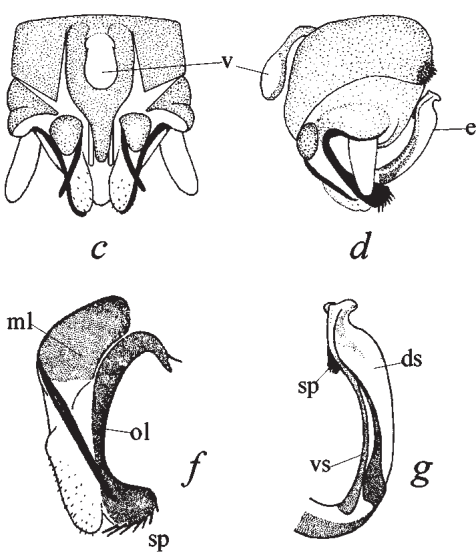

$d$

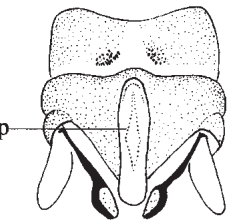

e
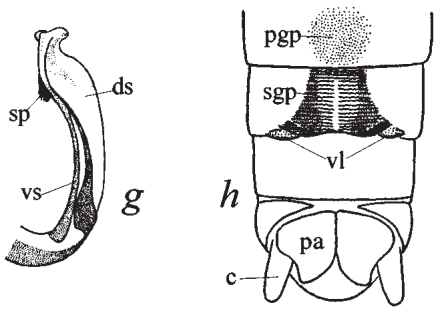

Fig. 1. Protonemura. Cervical gills in lateral view (a). Anterior wing of $P$. meyeri, with the characteristic «X» $(b)$. P. caprai : Tip of the male abdomen in dorsal $(c)$, lateral $(d)$ and ventral $(e)$ views; male paraproct $(f)$; male epiproct in lateral view $(g)$; female abdomen tip in ventral view $(h)$. Abbreviations: $\mathrm{c}=$ cercus; $\mathrm{ds}=$ dorsal sclerite il = inner lobe; $\mathrm{ml}=$ median lobe; $\mathrm{ol}=$ outer lobe; $\mathrm{pa}=$ paraproct; $\mathrm{sp}=$ spines; $\mathrm{v}=$ vesicle; $\mathrm{vl}=$ vaginal lobe; $\mathrm{vs}=$ ventral sclerite ( $a, f-h$ after Aubert; $b$ after Baumann; $c-e$ originals).

boneri, 800 m, 3 \%, 1-XI-99. Po Valley, Paesana, Pian Munè, 1530 m, 7 ơ, 7 ㅇ, 7-X-02 (Delmastro leg.). Varaita Valley, SW. Rossana, Lemma, $10^{7}, 27-X I I-94$. Maira Valley, crossroad to Comaglieres, 8 ㅇ, 2-XI-99. Grana Valley, NW. Valgrana, Piatta, 2 o", 4 ᄋ, 24-XII-94; 1 ơ, 3 ᄋ, 2-XI-99; SW. Monterosso Grana, Frise, 1 \&, 27-XII-94; Crissolo, Martino br., 1380-1400 m (Ravizza Dematteis \& Ravizza, 1988). Maritime Alps : Stura di Demonte Valley, Pietraporzio, Vallone de Pontebernardo, 1350 m, 3 o", 2 \% , 6-XI-02 (Delmastro leg.). Liguria, Ligurian Alps: Triora, Argentina trib., 650 m, 1 O’, 9-X-01; SW. Pieve di Teco, Rezzo, 560 m, 1 O', 28XII-94. Garéssio, Tanaro tributary, 650 m, 1 ㅇ, 10-X-01; S. Calizzano, Bardineto, Bormida di Millesimo spring, $820 \mathrm{~m}$, $10^{\prime \prime}, 1$ ㅇ, 11-X-01 (Fochetti leg.). Ligurian Apennines : NW. Savona, Monte San Giorgio, Porassino brook, 750 m, 2 ơ, 6 ㅇ, 5-XII-81 (Ravizza leg); Montenotte, Erro br., 750 m (Ravizza 1976). Emilia-Romagna : Emilian Apennines : Costiolo del Giovà, Staffora spring, 1300 m; Casalstaffora, Venera br., $1050 \mathrm{~m}$; Casanova S. Torbido br., 570 m (Ravizza 1974); Ferriere, inlet of Moo lake, 1200 m; Ferriere, Nure br., 550 m (Ravizza \& Ravizza Dematteis 1979); BedoniaCordolo, Lecca spring, 1500 m (Ravizza \& Ravizza Demat- teis 1978); Bedonia, Lecio tor., 1500 m, 12 ơ, 14 o, 25-IX76 (Ravizza leg); Lagdei di Corniglio, Parma br., 1250 m; Bosco di Corniglio, Parma, 950 m; Le Ghiare di Corniglio, Parma, 500 m (Ravizza Dematteis \& Ravizza 1994). Etymology : It is named padana, inhabiting the Po valley, from Padus the Latin name of the Po River; indeed $P$. ausonia padana mainly occurs along tributaries of the Po River in the western Alps and northern Apennines. Description : P. ausonia padana is a large species : body length, male 6.1-8.0, female, 7.5-11.0 mm. It is normally winged, male, forewing length 7.2-8.5, female, forewing length 9.1-11.1. Head and body dark brown; legs brownish with darker longitudinal strips. Male genitalia (Fig. 2 k-o) : Tergite VII with a slightly prominent group of strong spines medially on the posterior margin. Tergite VIII with two prominent groups of strong spines projecting backwards. Tergite IX similar to tergite VIII, but the notch between the two groups of spines is deeper. Sternite IX normal, basally with a racket-shaped well developed vesicle; the subgenital plate is distally ending in a tapering extension as usual in this genus. Tergite $\mathrm{X}$ with few tiny spines around epiproct tip. Epiproct slender in dorsal view, slightly widening before the tip. It terminates in a forked expansion (Fig. 2 o). Lateral sclerites thin, thread like, gently curved upwards near the epiproct tip (Fig. $2 \mathrm{~m}$ ). Ventral sclerite supporting a strong rounded projection with many long spines. In apical view, the ventral sclerite is forked (Fig. 2 n). Paraprocts: Inner lobe blade like and mostly hidden by the subgenital plate. Median lobe subtrapezoidal, narrowing toward the apex; it extends distally into a long, thin, sickle-shaped, sclerotized expansion (Fig. 2 k); this expansion is curved inwards and ends gradually into a sharp point. Outer lobe with a well developed membranous field and a strong cercal sclerite regularly bent around the cercus and carrying few apical spines (Fig. 2 1). Cerci well developed, slightly longer than the paraprocts. Female : Sternite VII with a postero-median well pigmented pregenital plate. Sternite VIII subgenital plate lips-shaped, slightly depressed along its midline. Vaginal lobes strong, subtriangular, well developed on each side of the subgenital plate (Fig. 2 p). Affinities : Closely related to P. ausonia ausonia from which it differs by the following features: In the male : - paraproct's median lobe with a long, thin, gently curved, sclerotized expansion (Fig. 2 k, 1); in $P$. ausonia ausonia, this expansion is not so long, stronger and about rectilinear (Consiglio 1955, Fig. 2$4)$, - paraproct's outer lobe with few terminal spines (2 to 6 , rarely more, Fig. 21 ), in $P$. ausonia ausonia the apical spines are much more abundant (15 to 30, rarely less) (Consiglio 1955, Fig. 4, 5), - presence of a well 

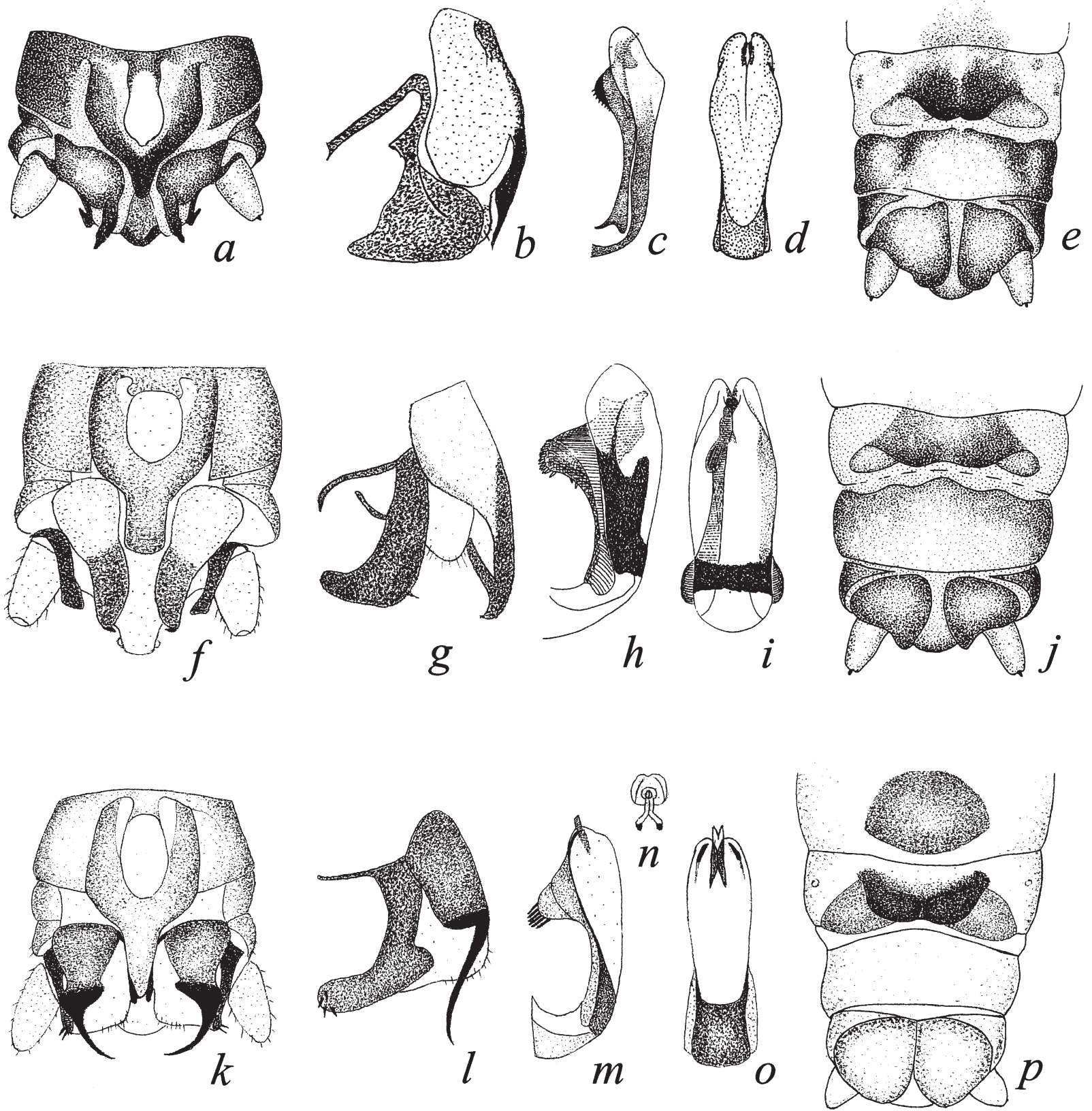

Fig. 2. P. culmenis : Tip of the male abdomen in ventral view (a), paraprocts in lateral view (b), epiproct in lateral view (c) and dorsal view (d) (Zwick, modified). Tip of the female abdomen in ventral view (e).P. tuberculata : Tip of the male abdomen in ventral view (f), paraprocts in lateral view (g) (Vinçon). Epiproct in lateral view (h) and dorsal view (i) (Berthélemy). Tip of the female abdomen in ventral view (j) (Vinçon). P. ausonia padana ssp. $\boldsymbol{n}$. : Tip of the male abdomen in ventral view (k), paraprocts in lateral view (l), epiproct in lateral view (m), apical (n) and dorsal view (o), tip of the female abdomen in ventral view (p) (Vinçon).

developed forked expansion at the tip of the epiproct (Fig. $2 \mathrm{~m}, \mathrm{o}$ ); in P. ausonia ausonia this forked expansion is not extending at the apex of the epiproct (Consiglio 1955, Fig. 1, 6); it is retracted inside the epiproct and sometimes visible by transparency. The females of $P$. ausonia padana differ by the wide subgenital plate, looking like lips (Fig. 2 p); in P. ausonia ausonia this subgenital plate is longer, and tongue shaped (Consi- 

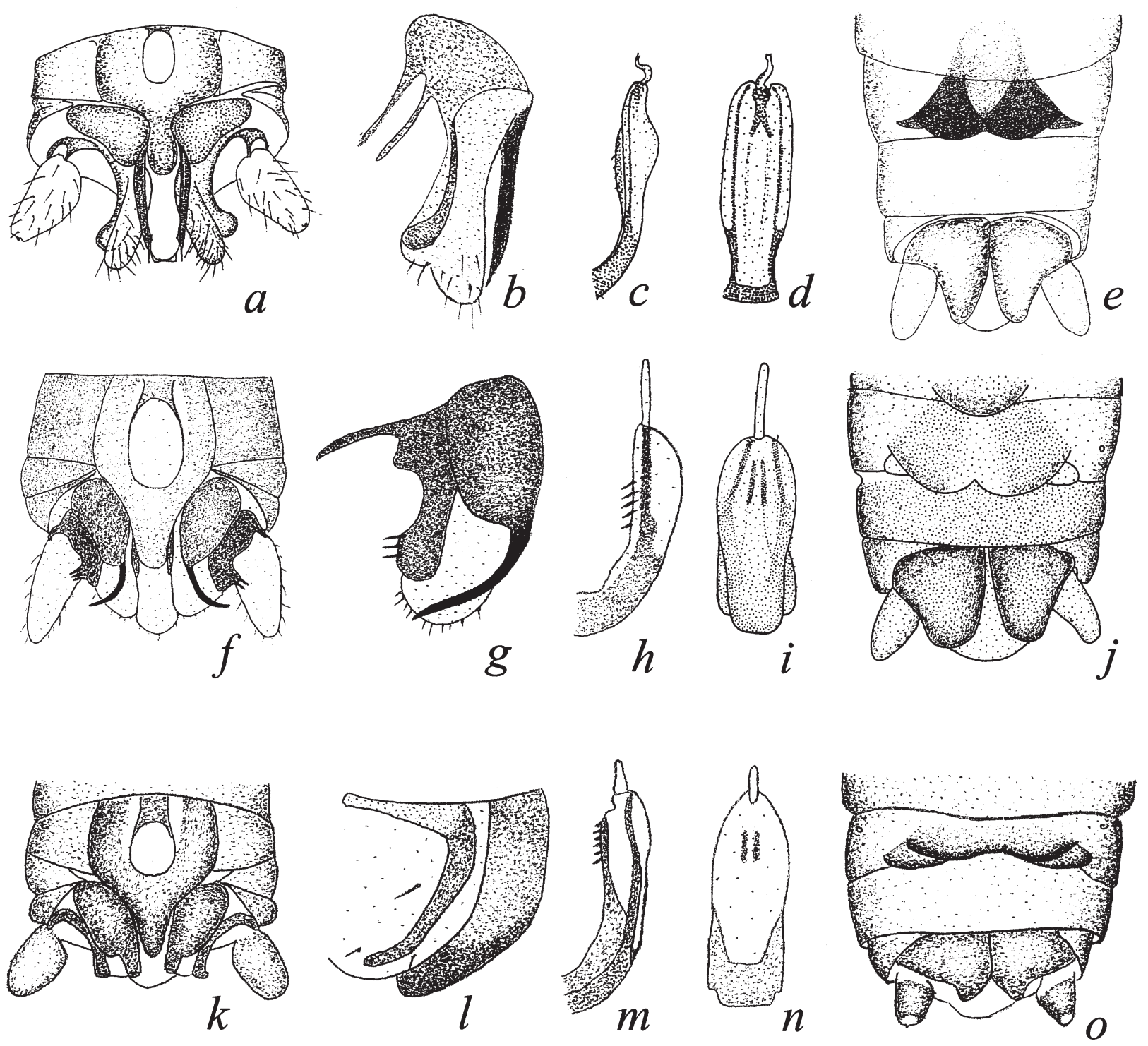

Fig. 3. P. canigolensis : Tip of the male abdomen in ventral view (a), paraprocts in lateral view (b), epiproct in lateral view (c) and dorsal view (d) (Zwick, modified). Tip of the female abdomen in ventral view (e) (Vinçon). P. corsicana : Tip of the male abdomen in ventral view (f), paraprocts in lateral view (g) (Vinçon). Epiproct in lateral view (h) and dorsal view (i), tip of the female abdomen in ventral view (j) (Consiglio). P. bucolica : Tip of the male abdomen in ventral view (k), paraprocts in lateral view (1), epiproct in lateral view (m) and dorsal view (n), tip of the female abdomen in ventral view (o) (Consiglio).

glio 1955, Fig. 8). Ecology : Crenophilic, stenothermous cold-water species, occurring in montane springs and brooklets (500-2000 m). It emerges in autumn (IXXII). Distribution : $P$. ausonia padana is an allopatric subspecies of $P$. ausonia. It occurs in the western Alps (Maritime and Cottian Alps, up to the Susa Valley) and northern Apennines (Liguria and Emilia-Romagna) while the typical $P$. ausonia inhabits the central and southern Apennines. The contact zone between the two geographic forms is the north of the Toscana and Marche where few specimens with intermediate characters were found. In the French Alps, it occurs close to the Italian border, on the southern slope of the Mercantour Massif (Roya and Vésubie valleys). 


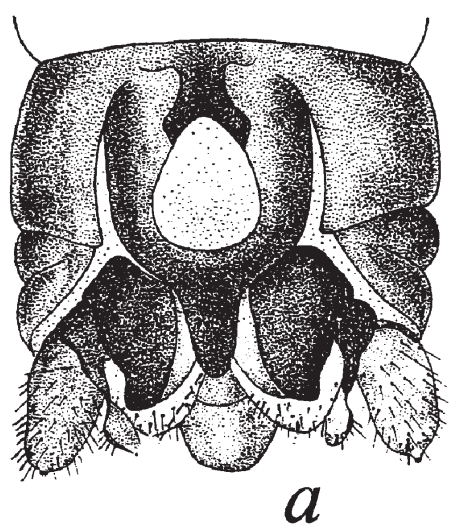

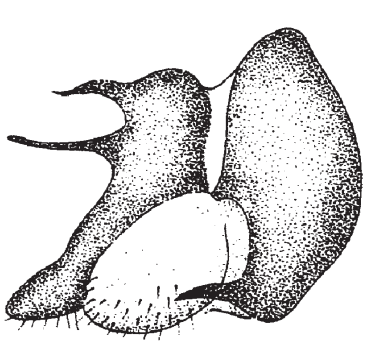

$b$

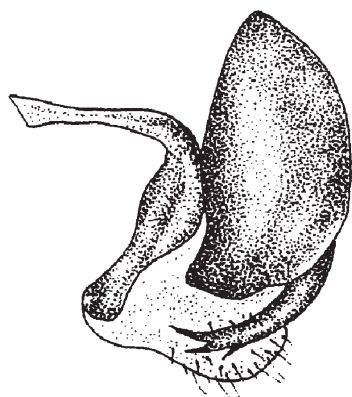

$f$

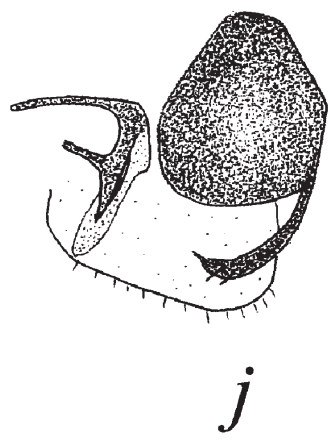

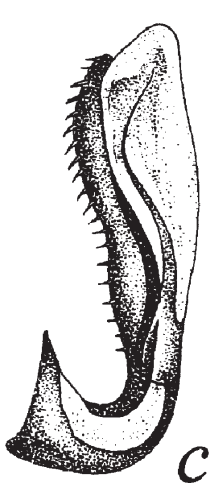
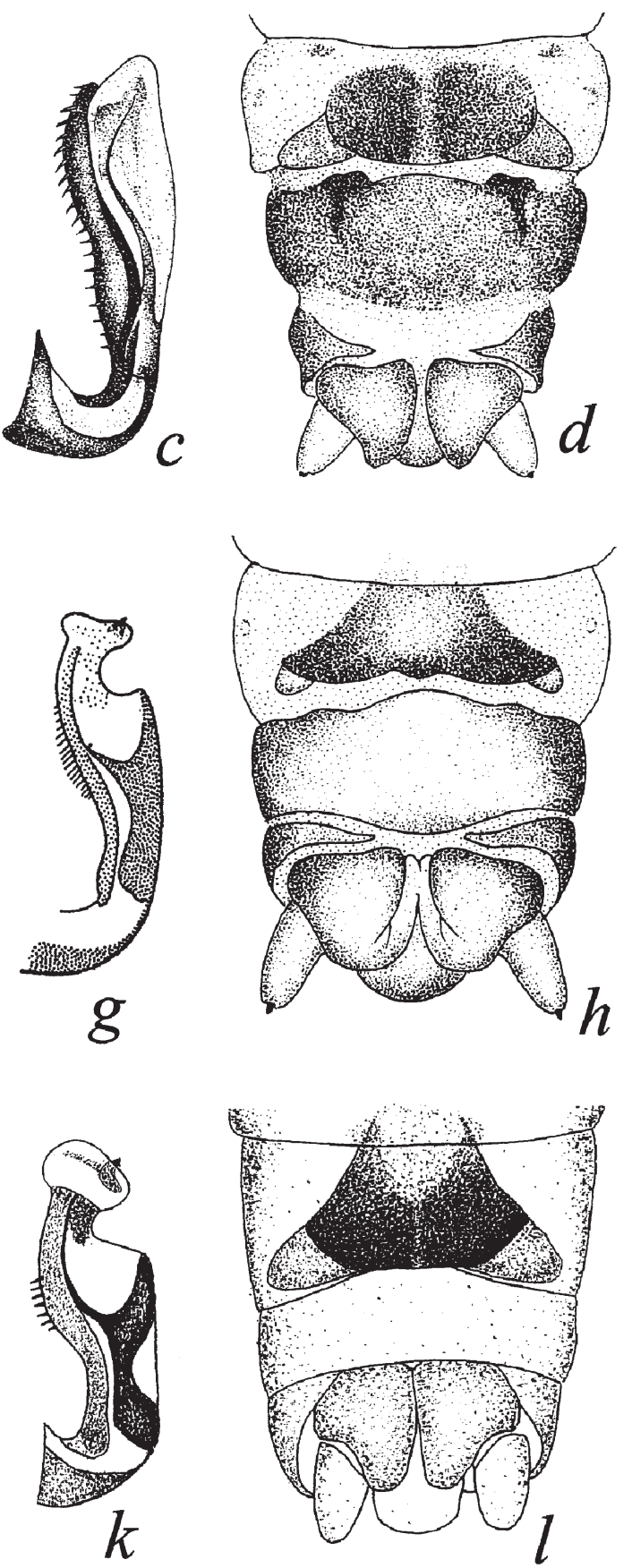

Fig. 4. P. praecox : Tip of the male abdomen in ventral view (a), paraprocts in lateral view (b), epiproct in lateral view (c), tip of the female abdomen in ventral view (d) (Kis). P. risi : Tip of the male abdomen in ventral view (e), paraprocts in lateral view (f), epiproct in lateral view (g), tip of the female abdomen in ventral view (h) (Kis). $\boldsymbol{P}$. spinulosa : Tip of the male abdomen in ventral view (i), paraprocts in lateral view (j), epiproct in lateral view (k), tip of the female abdomen in ventral view (l) (Vinçon). 

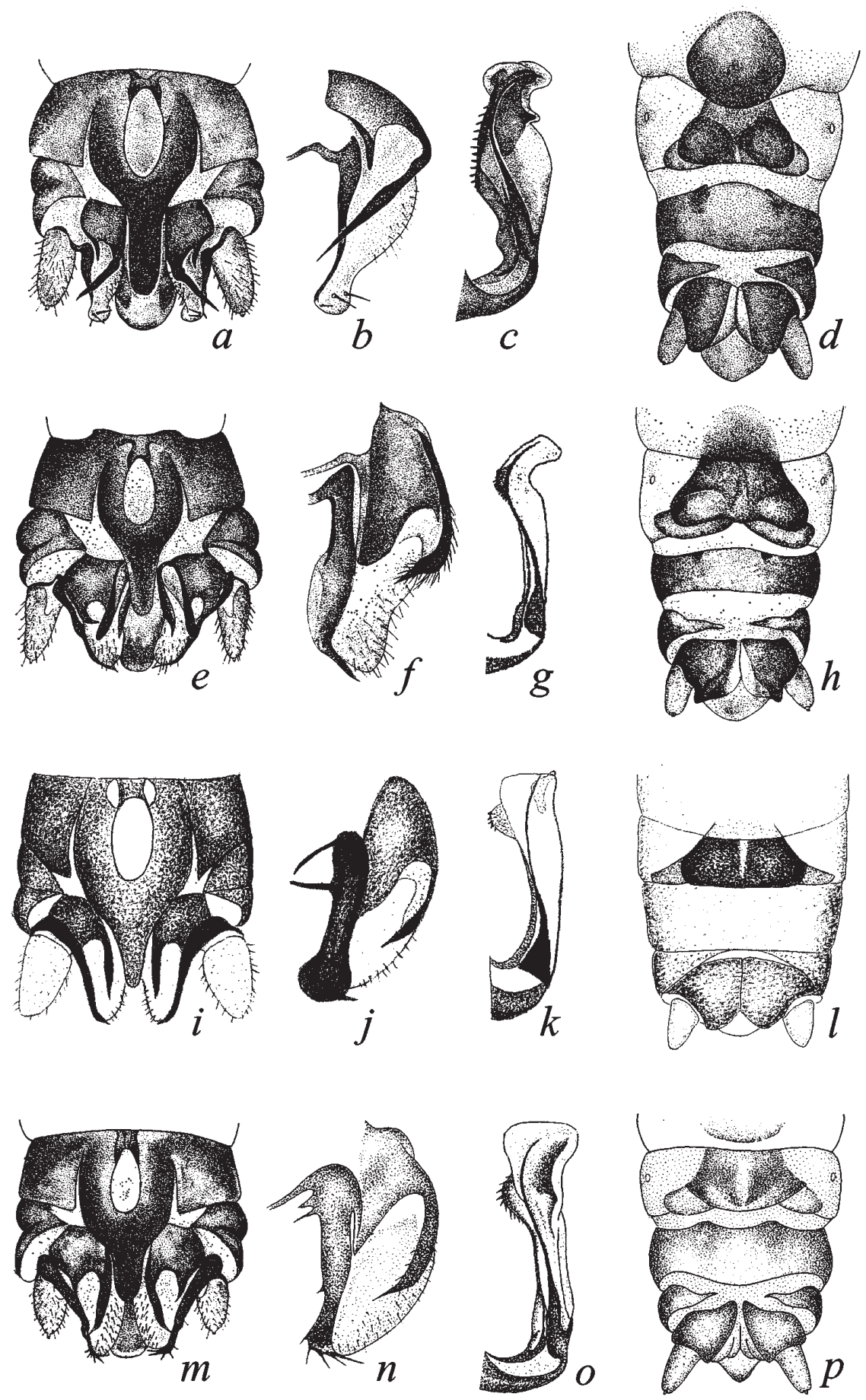

Fig. 5. P. intricata : Tip of the male abdomen in ventral view (a), paraprocts in lateral view (b), epiproct in lateral view (c). Tip of the female abdomen in ventral view (d) (Kis). P. nitida : Tip of the male abdomen in ventral view (e), paraprocts in lateral view (f), epiproct in lateral view (g). Tip of the female abdomen in ventral view (h) (Kis). P. zhiltzovae sp. $\boldsymbol{n}$. : Tip of the male abdomen in ventral view (i), paraprocts in lateral view (j), epiproct in lateral view (k), tip of the female abdomen in ventral view (1) (Vinçon). P. brevistyla : Tip of the male abdomen in ventral view $(\mathrm{m})$, paraprocts in lateral view $(\mathrm{n})$, epiproct in lateral view $(\mathrm{o})$, tip of the female abdomen in ventral view (p) (Kis). 

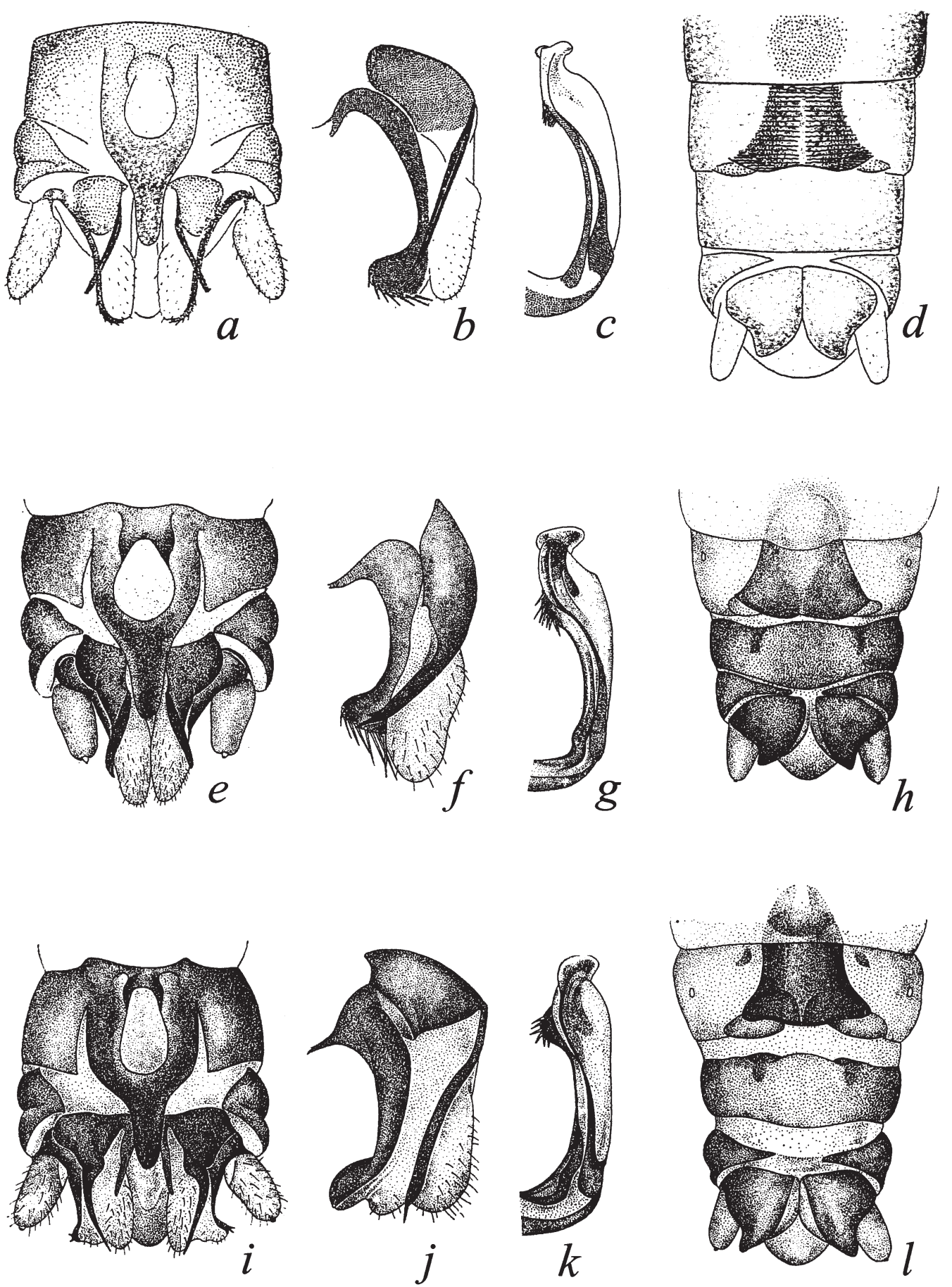

Fig. 6. P. caprai : Tip of the male abdomen in ventral view (a), paraprocts in lateral view (b), epiproct in lateral view (c), tip of the female abdomen in ventral view (d) (Aubert). P. lateralis : Tip of the male abdomen in ventral view (e), paraprocts in lateral view (f), epiproct in lateral view (g), tip of the female abdomen in ventral view (h) (Kis). P. meyeri : Tip of the male abdomen in ventral view (i), paraprocts in lateral view (j), epiproct in lateral view (k), tip of the female abdomen in ventral view (1) (Kis). 

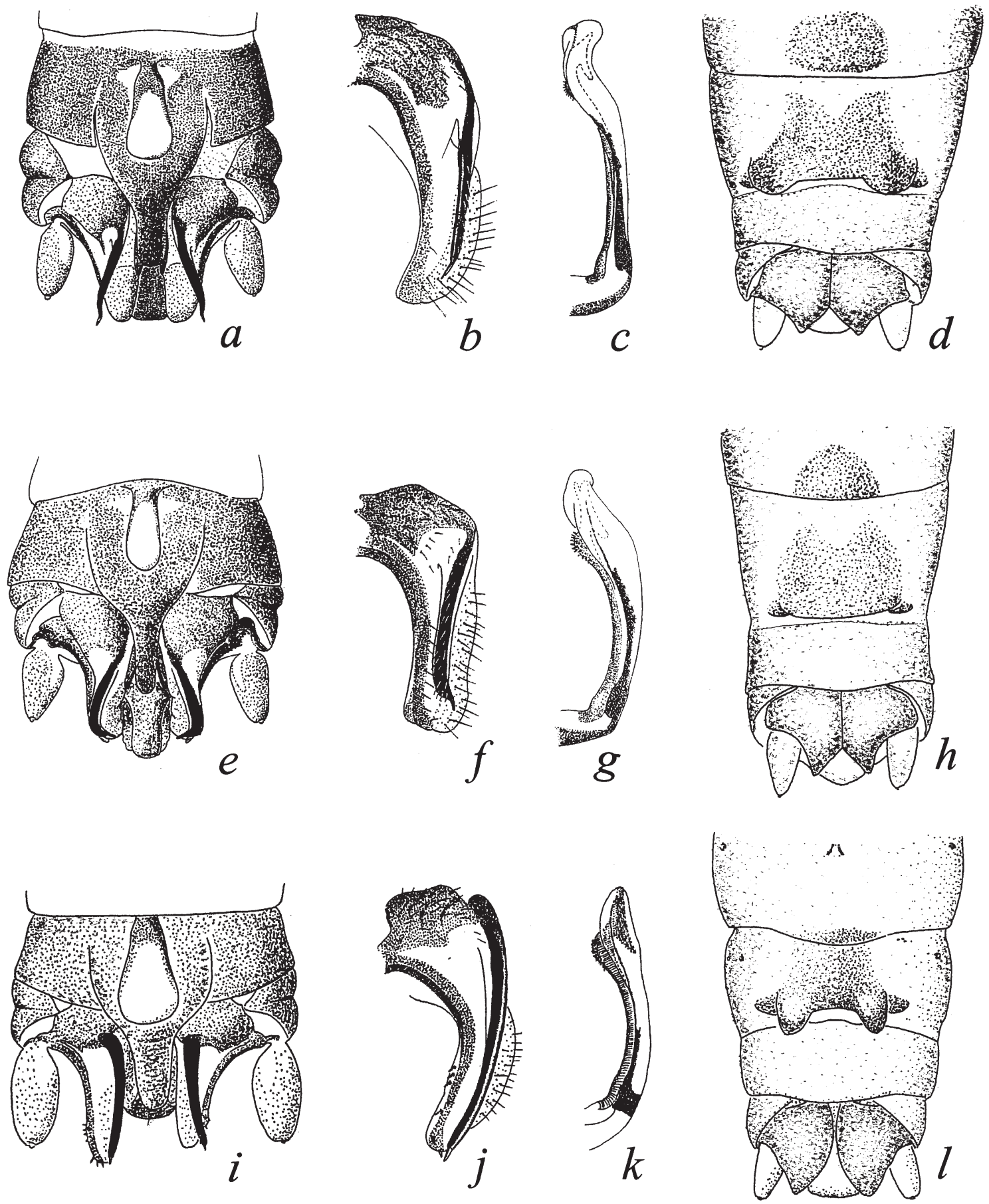

Fig. 7. P. beatensis : Tip of the male abdomen in ventral view (a), paraprocts in lateral view (b), epiproct in lateral view (c), tip of the female abdomen in ventral view (d) (Berthélemy). $\boldsymbol{P}$ vandeli : Tip of the male abdomen in ventral view (e), paraprocts in lateral view (f), epiproct in lateral view (g), tip of the female abdomen in ventral view (h) (Berthélemy). P. angelieri : Tip of the male abdomen in ventral view (i), paraprocts in lateral view (j), epiproct in lateral view (k), tip of the female abdomen in ventral view (l) (Berthélemy). 

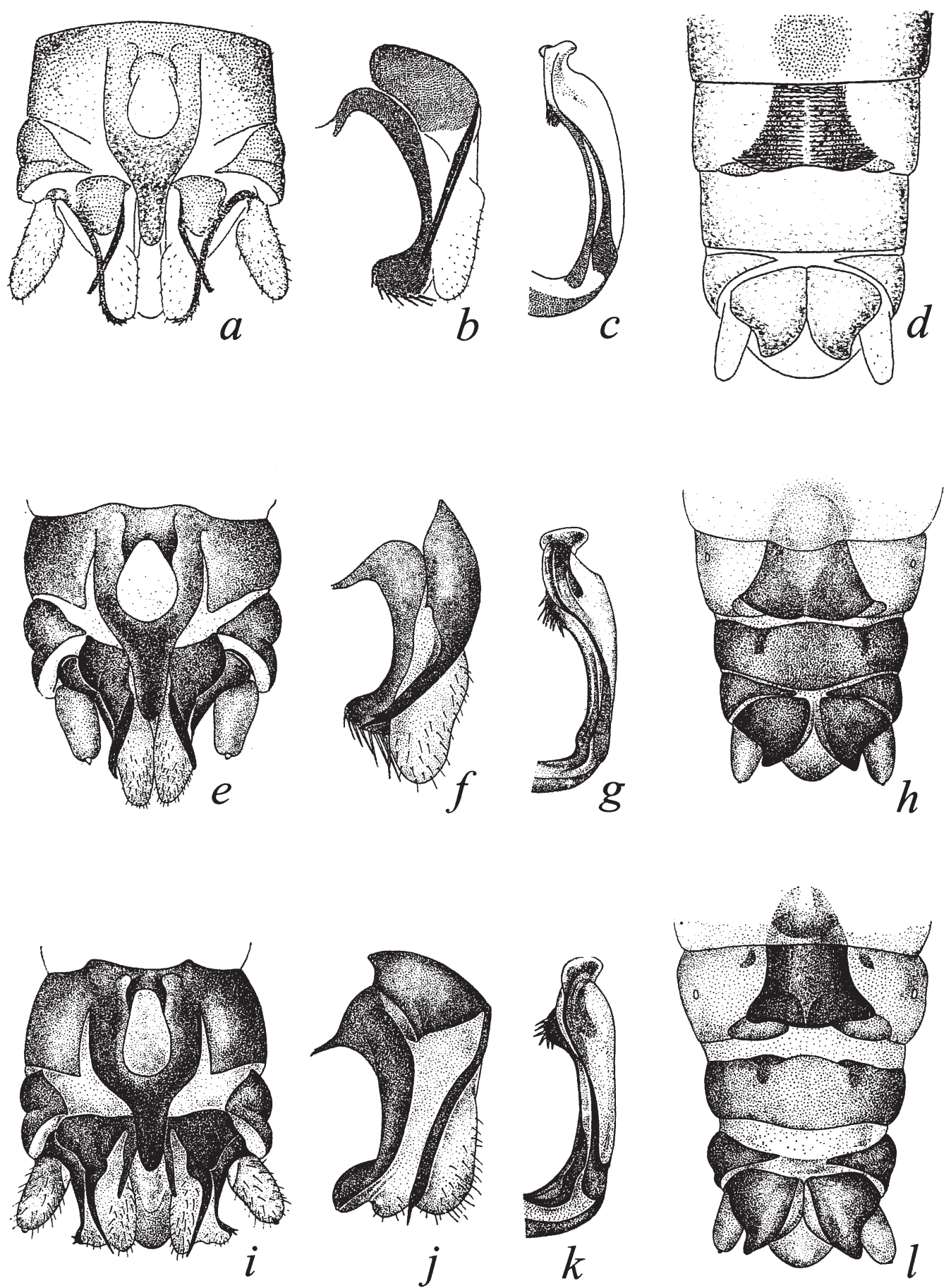

Fig. 8. P. pyrenaica : Tip of the male abdomen in ventral view (a) (Vinçon). Paraprocts in lateral view (b) (Aubert). Epiproct in lateral view (c); tip of the female abdomen in ventral view (d) (Vinçon). P. vercingetorix : Tip of the male abdomen in ventral view (e), paraprocts in lateral view (f), epiproct in lateral view (g), tip of the female abdomen in ventral view (h) (Aubert). P. nimborum : Tip of the male abdomen in ventral view (i), paraprocts in lateral view (j), epiproct in lateral view (k), tip of the female abdomen in ventral view (l) (Kis). 

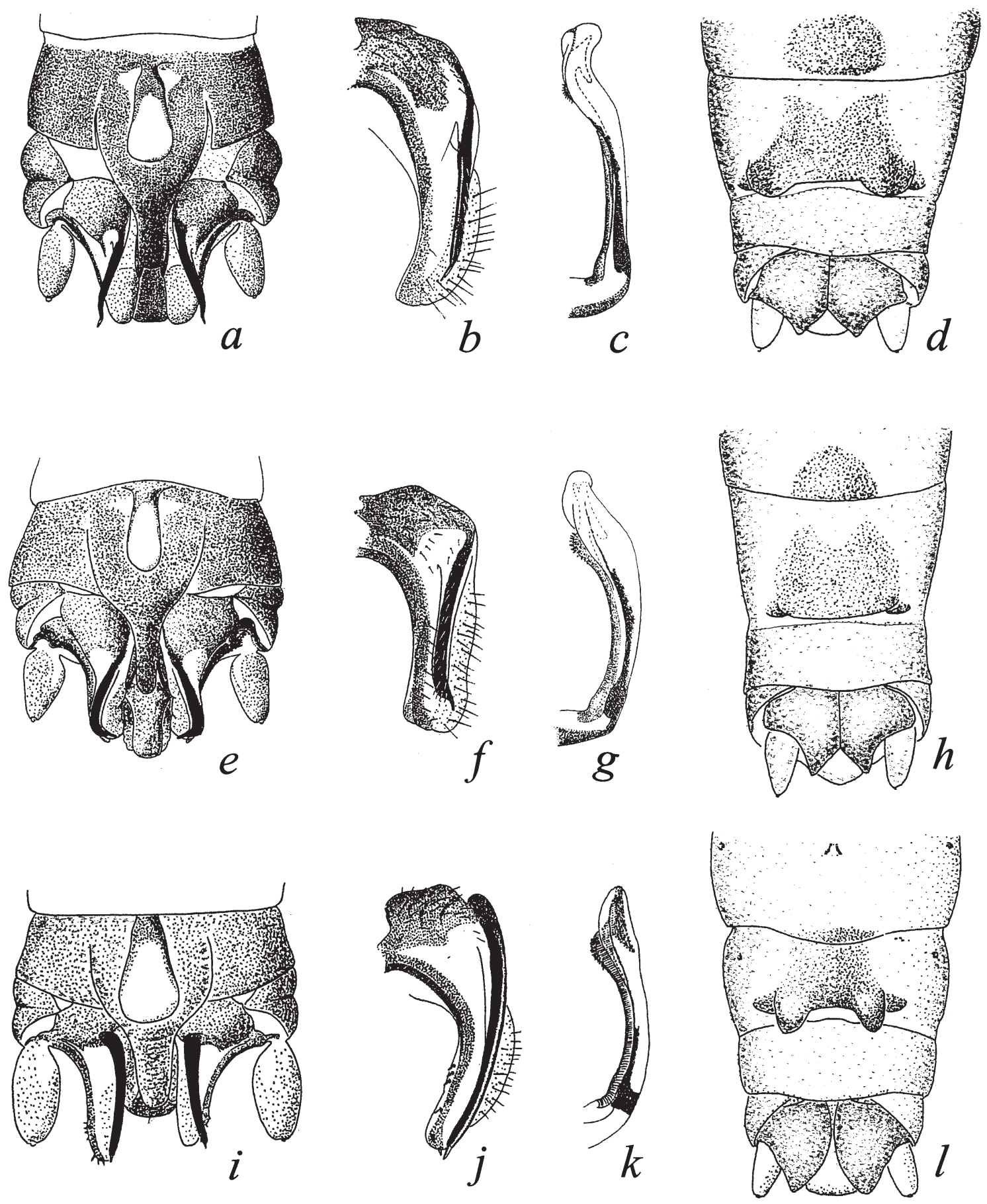

Fig. 9. P. nimborella : Tip of the male abdomen in ventral view (a), paraprocts in lateral view (b), epiproct in lateral view (c), tip of the female abdomen in ventral view (d) (Kis). P. montana : Tip of the male abdomen in ventral view (e), paraprocts in lateral view (f), epiproct in lateral view (g), tip of the female abdomen in ventral view (h) (Kis). P. algovia : Tip of the male abdomen in ventral view (i), paraprocts in lateral view (j), epiproct in lateral view (k), tip of the female abdomen in ventral view (l) (Mendl). 

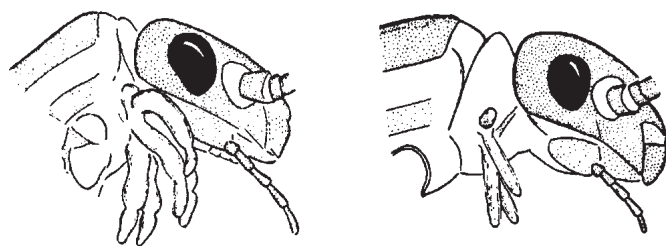

Fig. 10. Protonemura Cervical gills length, long at the left, medianshort at the right (after Aubert).

Protonemura ausonia ausonia Consiglio, 1955 (new status)

Nemoura (Protonemura) ausonia Consiglio, 1955 : 70 fig. 1-8.

Protonemura ausonia - Illies, 1966 : 224.

The typical $P$. ausonia ausonia (new status) does not occur in France but since we change its status, we give the list of the studied material from Central and Southern Italy. We do not give any description since the original drawings and description are precise enough
(Consiglio 1955). Material : Italy : Marche : Arcevia, Misa River, 400 m, 1 \%, 3-IV-91 (Terensi leg.); SW. Fabriano, Torre del Monaco, Esterna spring, 650 m, 1 ơ (intermediate form between the two subspecies), 1-VII-91 (Salerno leg.). Monte Sibillini, Tenna River, Gole Infernaccio, 1000 m, 3 o', 2 甲 (Fochetti leg.). Umbria : N. Nocera, Boschetto di Corleto, Fergia br., 600 m, VIII-92 (Salerno leg.); Foligno, Rasiglia Menotre River, 900 m, 2 o, 18-V-88; Mareite di Norcia, Chiappafreddo, 7 Q (Cianficconi leg.). Lazio : Rieti, Santa Susanna spring, 3 o', 6 ९, 7-X-81 (Cianficconi leg.). Abruzzes : l'Aquila, Vera spring, 1 O', 16-VI-88. Molise: Trigno River, 4 o, 1-XI-92 (Defanis leg.). Basilicata : N. Corleto Perticara, Fiumara di Corleto, 1 \&, 31-X-83 (Cianficconi leg.).

Protonemura canigolensis Zwick \& Vinçon, 1993 (Fig. 3 a-e) (Fig. 12)

Protonemura canigolensis Zwick \& Vinçon, 1993 : $54-56$ fig. 5 .

Material : Pyrenees : Pyrénées-Orientales. Type locality : Têt valley (Mont Canigou, Llitera stream,

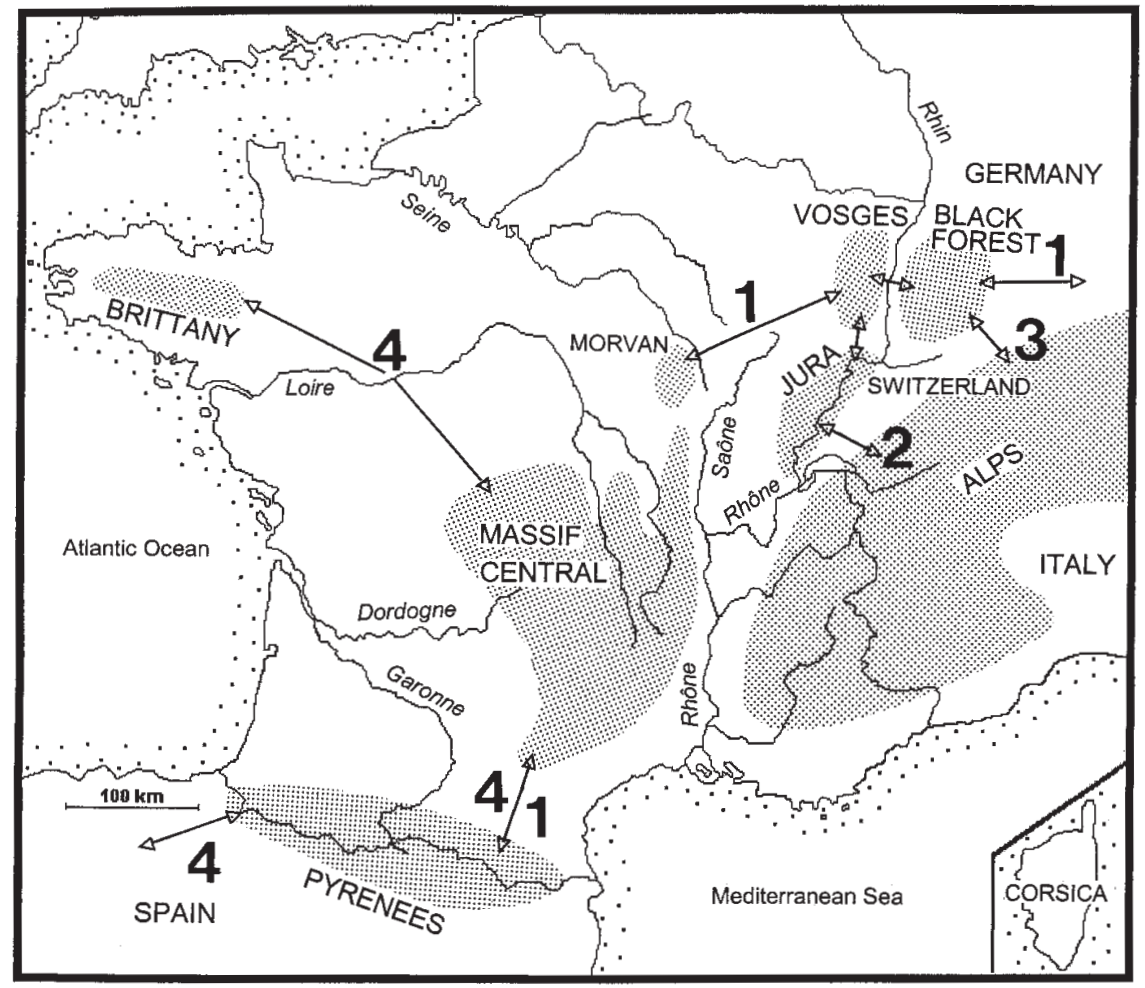

Fig. 11. French mountainous regions and main migration roads for orophilic species : 1 P. montana; 2 P. brevistyla; 3 P. lateralis and P. nimborum; $\mathbf{4}$ P. beatensis. 


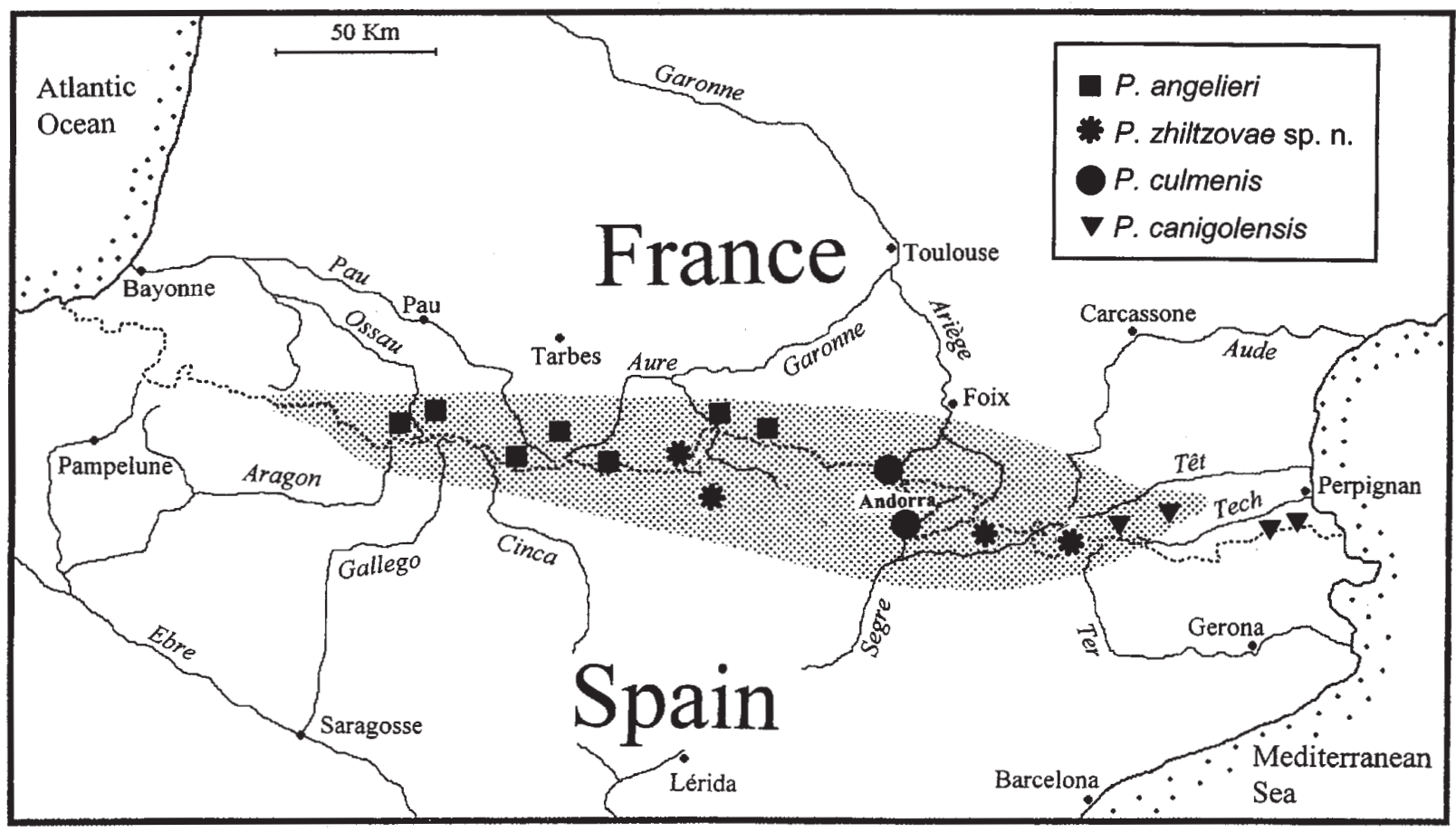

Fig. 12. Distribution of the 4 micro-endemic Protonemura species in the Pyrenees. The highest part of the chain (> 2000 $\mathrm{m}$ a.s.1.) is shaded.

1900 m a.s.1.), Pyrénées-Orientales, France. Etymology : The name derives from Mont Canigou, where all the specimens belonging to the type series were collected. Affinities : This species belongs to the «corsicana» group because of its epiproct filament. This filament is curved asymmetrical, while in all other species of the group it is straight, symmetrical. Ecology : Rheophilic, orophilic, and stenothermous cold-water species, endemic to the Eastern Pyrenees. It lives in springs and brooklets near their spring, at altitudes ranging from 600 to $2300 \mathrm{~m}$. Flight period in summer and autumn (VIII-XII). Distribution : This micro-endemic species is only known from the eastern extremity of the Pyrenees (Fig. 12) (Albères massif, Mont Canigou, Pic de la Dona). It probably occurs on the southern slope of the Pyrenees since we have collected it near the top of the Albères Massif, just 500 m from the Spanish border.

Protonemura corsicana (Morton, 1930) (Fig. 3 f-j) Nemoura corsicana Morton, 1930: 80-81 fig. 3-5.

Nemoura (Protonemura) corsicana - Despax, 1951: 70 fig. 29 ; Consiglio, 1957a : 127 fig. 7-8, 10-11.

Protonemura corsicana - Illies, 1966: 228.
Material : Corsica : Haute-Corse, Corse-du-Sud. Type locality : Corsica, France. Etymology : From Latin corsicanus $=$ inhabitant of Corsica. Affinities : Type species of the corsicana group. It is related to the Sardinian endemic P. ichnusae Consiglio, 1957a and the Sicilian endemic $P$. helenae Nicolai, 1985. Ecology : Orophilic and rheophilic species common in the montane zone (550-2000 m), where it is more frequent above $1000 \mathrm{~m}$. We have never collected it in the lower reaches. The adults have a long flight period (V-X). Distribution : Endemic to Corsica.

Protonemura bucolica (Consiglio, 1957) (Fig. 3 ko)

Nemoura (Protonemura) bucolica Consiglio, $1957: 128$ fig. 1-6, 9, 11.

Protonemura bucolica - Angelier, 1958 : 19; Illies, 1966 : 226-227.

Material : Corsica : Haute-Corse, Corse-du-Sud. Type locality : Corsica, Albertacce (between Popaja Forest House and Nino Lake, $1380 \mathrm{~m}$ ). Etymology : Derives from Latin bucolicus = belonging to shepherds, pastoral. Affinities : P. bucolica is closely related to the Sicilian endemic P. helenae Nicolai, 1985, that has a much longer expansion at the apex of the 


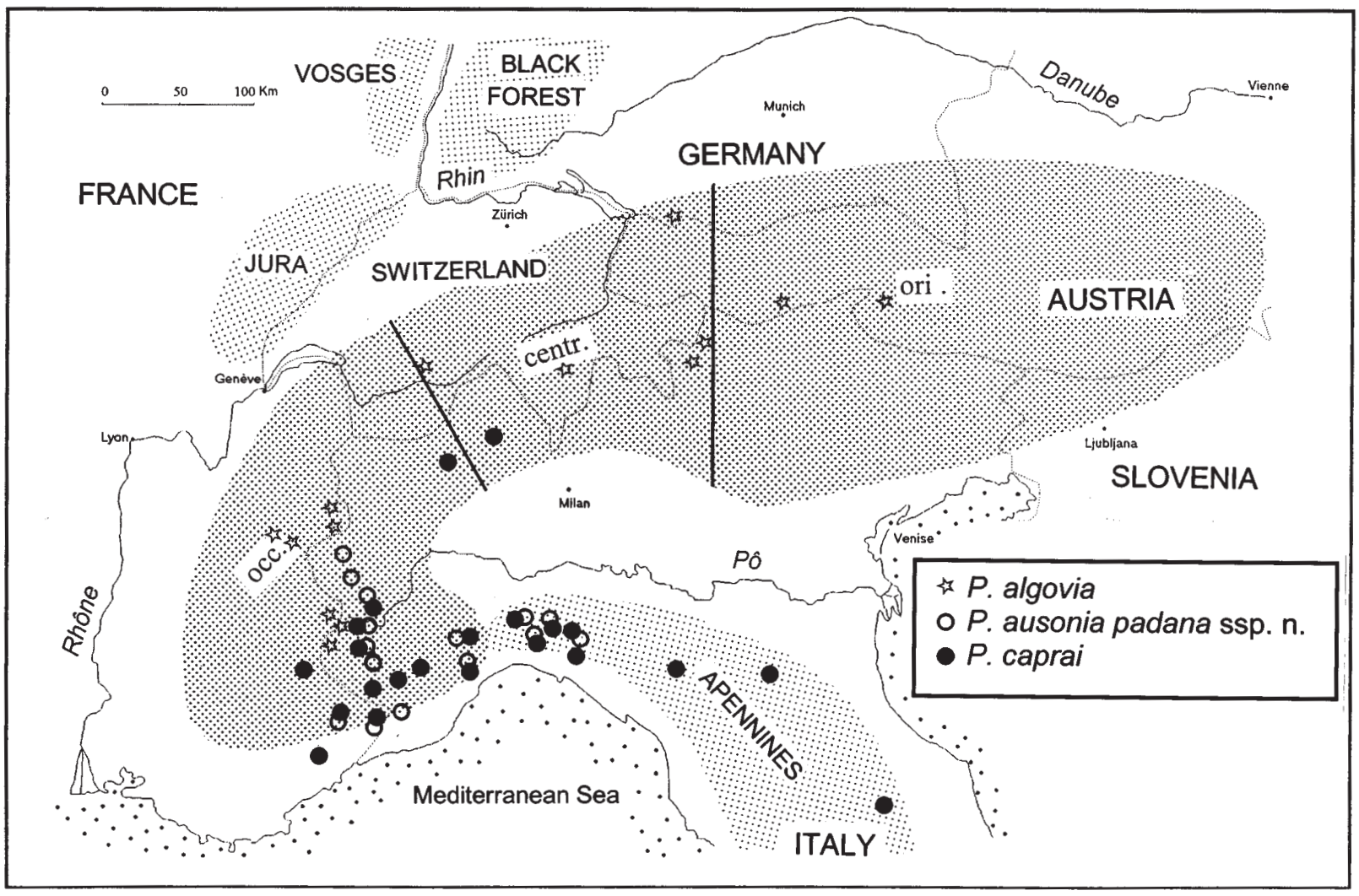

Fig. 13: Distribution of the P. algovia, P. ausonia padana ssp. n. and P. caprai in the Alps and northern Apennines (P. caprai also extends into the central Apennines).

male epiproct. It is also related to $P$. corsicana, from which the male differs by the shorter process arising from the epiproct apex, the clearly different shape of the paraprocts and the $9^{\text {th }}$ tergite hind margin less hollowed ; the female differs by the shape of the subgenital plate posterior margin (Fig. $3 \mathrm{j}$ and $3 \mathrm{~m}$ ). Ecology : Rheophilic and orophilic species, inhabiting high altitude brooks and brooklets (1000-1650 m). Emergence occurs in spring (V-VI). Distribution : Endemic to Corsica.

\section{praecox group}

Group characterized by the long, ventral sclerite of the epiproct. This sclerite is covered with a regular row of spines on the inferior face.

Protonemura praecox praecox (Morton, 1894) (Fig. 4 a-d)

Nemoura praecox Morton, 1894 : 566 fig. 13.

Nemoura (Protonemura) praecox - Ris, 1902 : 390 fig. 11-

\section{2; Despax, 1951 : 55 fig. 19.}

Protonemura praecox - Illies, 1955 : 40 fig. 25; Aubert, 1959 : 41 fig. 71, 78; 93; Illies, 1966 : 239; Kis, $1974: 169$ fig. 97.

Material : Alps : Isère, Hautes-Alpes, Alpes-de-HauteProvence. Massif Central : Aude, Lozère, Haute-Loire. Pyrenees : Pyrénées-Orientales, Hautes-Pyrénées, PyrénéesAtlantiques. Type locality : Clyde, Scotland, Great Britain. Etymology : From Latin praecox $=$ precocious, because adults emerge early in the year. Affinities : This species is clearly different from all the other French Protonemura species. Ecology : it inhabits small brooks of moderate altitude: $200-1200 \mathrm{~m}$ in the Alps (Vinçon 1996), up to $1900 \mathrm{~m}$ in the Pyrenees (1 o', 2 \%, Pyrénées-Orientales, Puigmal, Err brook, 1900 m, 8.V.91). Adults emerge in winter and early spring (IIV). Distribution : European species, occurring in all the French mountainous regions except Brittany and Corsica. 


\section{risi group}

Group characterized by the dorsal sclerite of the epiproct that is forked anteriorly in lateral view. The stem of the paraproct's median lobe has 2 or 3 apical spines. The sclerite of the paraproct's outer lobe has no apical spines. The cervical gills are very short, without any apical constriction.

Protonemura risi (Jacobson \& Bianchi, 1905) (new status) (Fig. 4 e-h)

Nemoura (Protonemura) fumosa Ris, 1902 : 387 fig. 5-6 (nec Stephens, 1835).

Nemoura risi Jacobson \& Bianchi, 1905: 562.

Protonemura fumosa - Illies, 1955: 43 fig. 30; Aubert, 1959 : 41 fig. $70,82,89$.

Protonemura risi - Illies, 1966 : 241; Kis, 1974:169-170 fig. 98.

In this work $P$. spinulosa is no more considered as a subspecies of $P$. risi.

Material : Alps : Savoie, Isère, Drôme, Hautes-Alpes, Alpes-Maritimes. Jura : Ain, Jura, Doubs. Vosges : HautRhin. Brittany : Ille et Vilaine. Massif Central : Aude, Tarn, Gard, Ardèche, Lozère, Loire, Puy-de-Dôme, Saôneet-Loire. Type locality : Schaffhausen, Switzerland. Etymology : Named after the Swiss plecopterologist F. Ris. Affinities : Close relative of P. spinulosa (see following description). Ecology : Crenophilic species inhabiting brooklets and springs in the foothills and montane zone (250-1500 m), with a preference for calcareous substratum in the pre-alpine massifs. It has a long emergence period (V-X). Distribution : Central European species found in the Carpathians, Alps, Jura, Vosges, Brittany and Massif Central. It is replaced in the Pyrenees by its sister species $P$. spinulosa.

Protonemura spinulosa (Navás, 1921) (new status) (Fig. 4 i-1)

\section{Nemoura spinulosa Navás 1921 : 75 fig.3}

Protonemura fumosa occidentalis Despax 1929, 83 fig. 13; Despax, 1951: 65 fig. 26; Aubert, 1952: 250 fig. 7; Illies, 1966: 240

The study of numerous specimens coming from the southern part of the French Massif Central (Aigoual and Montagne Noire) shows that the specimens assigned to P. risi spinulosa in this region (Aubert 1963, Berthélemy 1965) belong to $P$. risi. Since the two species are clearly different in both sexes, $P$. spinulosa is restored to the specific level and a new description of the male and female genitalia is given. Material : Pyrenees : Pyrénées-Orientales, Ariège, Haute-Garonne, Hau-
te-Pyrénéees, Pyrénées-Atlantiques. Type locality : Spanish Pyrenees. Etymology : From Latin spinosus $=$ thorny, spiny, with spines. Genitalia description : $\mathrm{Pa}-$ raproct's median lobe small, rounded, about as wide as long. It is prolonged backwards and outwards by a short thin expansion with 2 or 3 apical spines (Figs 4 ij). The sclerite of the outer lobe is very short, with a basal branch turning around the cercus and a thin lateral branch starting from the middle of the sclerite (Fig. 4 j). Epiproct with a median widening followed by a deep depression just before the rounded apex. A tiny sclerite sometimes projects upward from the epiproct's apex (Fig. 4 k). Ventral sclerite of the epiproct with a median bulge covered with several short spines. Female: Subgenital plate with a median depression and a rounded posterior edge. The lobes are triangular, well developed on each side of the plate (Fig. 4 1). Affinities : Closely related to $P$. risi from which it differs by the following features : in the male, the base of the paraproct's median lobe is almost globular in $P$. spinulo$s a$ (Fig. $4 \mathrm{j}$ ), and much longer than wide in $P$. risi (Fig. $4 \mathrm{f}$ ). The outer lobe sclerite is thin, with a sclerotized lateral branch (Fig. $4 \mathrm{j}$ ); in $P$. risi it is stronger, without any lateral branch (Fig. $4 \mathrm{f}$ ). The epiproct of $P$. spinulosa has a median widening (Fig. $4 \mathrm{k}$ ) not so pronounced in P. risi (Fig. $4 \mathrm{~g}$ ). The epiproct's apex is also slightly more rounded in P. spinulosa (Fig. $4 \mathrm{k}$ ). The female subgenital plate of $P$. spinulosa is convex, not covering the lateral lobes which are well developed on each side of the plate (Fig. 4 1); in P. risi the subgenital plate is much wider and concave, covering about the totality of the hardly visible lateral lobes (Fig. 4 h). Ecology : This strongly crenophilic, stenothermous cold-water species occurs mainly in springs and brooklets between 300 and $2200 \mathrm{~m}$. It has a very long emergence period (III-X). Distribution : North Iberian Peninsula : Pyrenees, Cantabrian Cordillera and Sierra de la Demanda (Vinçon \& Pardo 2004).

\section{intricata group}

Group characterized by the globular tip of the outer lobes of the paraprocts. The median lobes mainly end in a rather long, blade-shaped expansion (style). The epiproct is erect at the tip and has a deep depression just before the tip.

Protonemura intricata intricata (Ris, 1902) (Fig. 5 a-d)

Nemoura (Protonemura) intricata Ris, 1902: 392 fig. 1516.

Nemoura (Protonemura) intricata - Despax, 1951 : 57 fig. 21. 
Protonemura intricata - Illies, 1955 : 44 fig. 21; Aubert, 1959: 43 fig. 77, 80, 91.

Protonemura umbrosa - Illies, 1966 : 245, nec Aubert, nec A.E. Pictet.

Material : Alps : Savoie, Isère, Drôme, Vaucluse, Hautes-Alpes, Alpes-de-Haute-Provence, Alpes-Maritimes. Jura : Ain, Jura, Doubs. Vosges : Haut-Rhin. Brittany : Finistère (Ledoare com. pers.). Normandy : Manche. Massif Central : Tarn, Ardèche, Lozère, Loire, Puy-de-Dôme, Saône-et-Loire. Pyrenees : Pyrénées-Orientales, Ariège, HauteGaronne, Hautes-Pyrénées, Pyrénées-Atlantiques. Type locality : Mendrisio, Switzerland. Etymology : Unknown. Affinities : It is clearly different from all the other French Protonemura species. Ecology : This eurytopic species occurs in various kinds of watercourses in the montane zone and foothills, mainly between 150 and $1400 \mathrm{~m}$, and sometimes much higher, up to 2400 $\mathrm{m}$ in Andorra, Coma Pedrosa, Arinsal, $10^{7}, 14-\mathrm{VII}-86$. Distribution : This Central South European species is common in all the French Massifs and even in the lowland rivers.

\section{nitida group}

The three groups, nitida, nimborum and meyeri, defined by Rauser, 1962, are so closely related that it is difficult to characterize them. We prefer to gather them in a single group, mainly characterized by the shape of the epiproct. It is elongated, often widening near the apex. The spines of the ventral sclerite are gathered, forming a pre-apical bulge.

\section{Protonemura nitida (Pictet, 1835) (Fig. 5 e-h)}

Nemoura nitida Pictet, 1835 : fig. 3, nec nitida Stephens, 1835

Nemoura (Protonemura) nitida - Ris, 1902 : 335 fig. 1-2; Despax, 1951 : 61 fig. 23.

Protonemura nitida - Illies, 1955: 45 fig. 33; Aubert, 1959: 43 fig. 76, 85, 94 (nec 75, 95); Kis, 1974: 179-180: fig. 105.

Material : Alps : Haute-Savoie, Savoie, Isère, Drôme, Hautes-Alpes, Alpes-de-Haute-Provence, Alpes-Maritimes. Jura : Ain, Doubs. Massif Central : Puy-de-Dôme. Type locality : Hertford, England, Great Britain. Etymology : From Latin nitidus = neat, bright. Affinities : Related to both $P$. brevistyla and $P$. zhiltzovae sp. n. from which it mainly differs by the paraprocts outer lobe and the epiproct. Ecology : Eurytopic species inhabiting various kinds of watercourses between 200 and $2300 \mathrm{~m}$. Its higher record in the French Alps is in the Vanoise Massif, Savoie, Bonneval-sur-Arc, below Iseran pass at $2300 \mathrm{~m}, 2 \mathrm{O}^{7}, 6-\mathrm{X}-90$. It emerges in autumn (IX-XII). Distribution : Central European species re- ported from the Carpathians, Alps, German Black Forest, Vosges, Jura and French Massif Central.

Protonemura zhiltzovae sp. n. (Fig. 5 i-1) (Fig. 12)

Protonemura brevistyla - Zwick \& Vinçon, 1993.

Holotype male : France, Pyrénées-Orientales, Err, Puigmal Mount, Err brook, Sègre tributary, 2250 m, 27-VIII-86. The holotype and $30^{7}, 4$ O paratypes are deposited in the Zoological Museum of Lausanne, Switzerland. Other paratypes, same date and locality, 80 o', 51 ㅇ; Err brook, 1900 m, 1 ơ, 1 우, 3-VII-88 (held in Vinçon collection). Other material : France : Pyrénées-Orientales, Eyne, Eyne spring, Sègre trib., 2200 m, 4 0", 4 ㅇ, 28-VII-87. Haute-Garonne, Bagnères-de-Luchon, Port-de-Venasque Pass, Pique spring, 2100 m, 1 ơ, 22-X-89. Spain : Catalogne, Girona, Between Puigcerda and Bellver de Cerdanya, Maranges, S. Puig-Pédros Mount, «Folch Refuge», Duran spring, 2000 m, 1 \% , 7-VII-87. Aragon, Huesca, Aneto Massif, W. Beserca dam, Salenques spring, 2000 m, 1 o, 11-IX-86. Etymology : Named after Professor Lidija Zhiltzova for her great contribution to the knowledge of Asiatic and European stoneflies. Description : A very small Protonemura species : body length, male 3.1-4.9 mm, female 5.5-6.3 mm. Male brachypterous : forewing length $1.8-2.6 \mathrm{~mm}$; female fully winged : forewing length $5.5-7.0 \mathrm{~mm}$. Head and body brown, legs light brown. Cervical gills of medium size (slightly longer than the diameter of an eye), with a slightly visible pre-apical constriction. Male genitalia (Fig. 5 i-k) : Tergite VIII with few scattered spines medially on the posterior margin. Tergite IX with two hardly prominent groups of spines separated by a narrow notch. Sternite IX normal: subgenital plate with a tapering extension distally and a racket-shaped well developed vesicle. Tergite X with a median membranous area around epiproct tip. Epiproct slender in dorsal view, with nearly parallel sides and triangular apex; it terminates in a short expansion projecting upwards (Fig. 5 k). Lateral sclerites thin, thread like, gently curved upwards near the epiproct tip (Fig. 5 k). Ventral sclerite supporting a rounded projection with many short spines. Paraprocts: Inner lobe hidden by the subgenital plate. Median lobe rounded, extending distally into a short sclerotized expansion, about rectilinear and ending into a strong spine (Fig. 5 i). Outer lobe sclerite strong, ending in a rounded plate that carries one or exceptionally two spines (Fig. 5 j). Cerci well developed, about as long as the paraprocts. Female : Sternite VIII subgenital plate with a median depression and a rectilinear posterior margin. Vaginal lobes extending on each side of the subgenital plate (Fig. 5 1). Affinities : P. zhiltzovae sp. n. belongs to the 
nitida group. It is related to $P$. brevistyla from which it differs by the epiproct that has a small expansion on the upper side (Fig. $5 \mathrm{k}$ ); by the paraprocts outer lobe that has only one apical spine in P. zhiltzovae (Fig. 5 j) and more than five spines in P. brevistyla (Fig. $5 \mathrm{n}$ ). The female subgenital plate is also very different, with a rectilinear posterior margin in P. zhiltzovae (Fig. 5 l) and a triangular one in P. brevistyla (Fig. 5 p). P. zhiltzovae is also related to the Iberian species $P$. navacerrada Aubert, 1954; indeed the epiprocts are rather similar in side view, with a small expansion on the apex upper side (Fig. $5 \mathrm{k}$ and Aubert 1954 Fig. 16, 17). This expansion is reminiscent of the terminal filament that is characteristic of the corsicana group, but clearly both species share more affinities with the nitida group. Ecology : It is a strongly crenophylous, stenothermous cold-water species, restricted to very high altitude springs (1900-2250 $\mathrm{m}$ a.s.1.). The adults hide under the stones and in the dense aquatic vegetation that develops along the first reach of the springs. Emergence is in summer and autumn (VII-X). Distribution : Endemic to the eastern half of the Pyrenees (Fig. 12). It extends from the Cerdagne (Pyrénées-Orientales) up to the Pique Valley (Haute-Garonne), and on the southern slope it occurs in the high Sègre Valley, from the Cerdagne (Girona) up to the Aneto Massif (Huesca).

Protonemura brevistyla (Ris, 1902) (Fig. 5 m-p) (Fig. 11, arrow 2)

Nemoura (Protonemura) brevistyla Ris, 1902 : 386 fig. 34.

Nemoura (Protonemura) brevistyla - Despax, 1951 : 62 fig. 24.

Protonemura brevistyla - Illies, 1955 : 45 fig. 32; Aubert, 1959 : 44 fig. 75, 83, 95 (nec 76, 94); Illies, 1966 : 225; Kis, 1974 : 178 fig. 104.

Material : Alps : Savoie, Isère, Hautes-Alpes, Alpes-deHaute-Provence, Alpes-Maritimes. Jura : Doubs. Type locality : Silvaplana, Switzerland. Etymology : The name refers to the very short sclerotized stem of the paraproct's median lobe. Affinities : P. brevistyla is closely related to the Pyrenean species $P$. zhiltzovae sp. n. (see following description). It is also related to $P$. niti$d a$ from which it clearly differs by the shape of the paraprocts outer lobe (Fig. 5 f, j) and epiproct (Fig. 5 g, k). Ecology : In the occidental Alps, P. brevistyla is one of the most strongly orophilic species (Ravizza \& Ravizza Dematteis, 1994). Indeed, it occurs in high altitude brooks and torrents $(1250-2600 \mathrm{~m})$ but more frequently in the sub-alpine and alpine zones, above 1600 $\mathrm{m}$. The highest record is in the Queyras massif (Hautes-Alpes, Echalp, Guil tributary above Egour- geou lake, $2600 \mathrm{~m}, 9$ ơ, 13 o, 4-IX-88). The adults emerge in summer and autumn (VII-X). Distribution : Alpino-Carpathian species, Jura. The mention of $P$. brevistyla in the Pyrenees (Zwick \& Vinçon 1993) corresponds to $P$. zhiltzovae sp. n.

Protonemura caprai (Aubert, 1954) (Fig. 6 a-d) (Fig. 13)

Nemoura (Protonemura) caprai Aubert, 1954 : 108-109 fig. 1-6.

Protonemura caprai - Illies, $1966: 227$.

Material : Alps : Alpes-Maritimes. Type locality : Italy, Ligurian Alps, Magliolo, Maremola stream, $250 \mathrm{~m}$. Etymology : Named after the Italian entomologist Felice Capra. Affinities : closely related to P. lateralis from which it differs in the following features : the sclerotized expansion of the paraproct's median lobe is much thinner in P. caprai (Fig. 6 a-b, 6 e-f), and the apex of the outer lobe is rounded with a regular row of short spines (Fig. 6 b) while in P. lateralis the spines are shorter on the outer edge and much longer on the inner edge (Fig. $6 \mathrm{f}$ ). The females of both species are so close that they cannot be separated with certainty. $P$. caprai is also strongly related to $P$. costai Aubert, 1953 with which it has often been confused (Consiglio 1955, 1958, see Consiglio 1979, Nicolai \& Fochetti 1983 and Fochetti \& Nicolai 1988). Ecology : Rheophilic species living in various kinds of brooks and torrents in the montane zone $(250-1600 \mathrm{~m})$. The adults have a very long flight period (IV-XI), but are more frequent in spring (V-VI). Distribution : Its distribution covers the northern and central Apennines and the Western Alps (Fig. 13). In the Apennines, it extends up to the Abruzzes and Lazio (Consiglio 1958 sub nom. $P$. costai, Consiglio 1979). In the Alps, its northeastern limit is the Val Diveria on the eastern edge of the Pennines Alps and its western limit is in the French Maritime Alps (Var Valley).

Protonemura lateralis (Pictet, 1835) (Fig. $6 \mathrm{e}-\mathrm{h}$ )

Nemoura lateralis Pictet, 1835 : 180 fig. 4.

Nemoura (Protonemura) lateralis - Ris, 1902 : 388 fig. 78; Despax, 1951, 59 fig. 22.

Protonemura lateralis - Illies, 1955: 42 fig. 28; Aubert, 1959 : 43 fig. 73, 79, 96; Kis, 1974 : 184-185 fig. 100.

Material : Alps : Haute-Savoie, Savoie, Isère, Drôme, Hautes-Alpes, Alpes-de-Haute-Provence, Alpes-Maritimes. Jura : Doubs. Type locality : Genève, Switzerland (Illies, 1966). Etymology : The specimen studied by Pictet showed a «lateral» yellowish margin around the pronotum, a feature of other Protonemura species. Af- 
finities : $P$. lateralis is related to $P$. caprai (see previous description of $P$. caprai). Ecology : Rheophilic, orophilic species very common and abundant in the montane and sub-alpine zones $800-2500 \mathrm{~m}$. Its highest locality in the French Alps is in the Oisans Massif (Hautes-Alpes, Dormillouse, Rully River at 2500 m, 5 ơ, 9 \%, 16-VII-92); in Italy it reaches $2750 \mathrm{~m}$ (Ravizza \& Ravizza Dematteis 1994). In France, it also occurs in cold low altitude springs : Isère, Sassenage, Germe River, below the cave "Cuve de Sassenage», 200 m, 2 o', 4 ㅇ, 12-V-91. Adults emergence long (IVXI). Distribution : Central European species, from the Carpathians and the whole Alpine Chain. It also extends northwards into Germany (Reusch \& Weinzierl 1999), and into the Jura and Vosges Massifs.

\section{Protonemura meyeri (Pictet, 1841) (Fig. 6 i-1) \\ Nemoura meyeri Pictet, 1841 : 390.}

Nemoura (Protonemura) meyeri - Ris, 1902 : 391 fig. 1314 ; Despax, 1951 : 63 fig. 3, 25.

Protonemura meyeri - Illies, 1955: 40 fig. 27; Aubert, 1959 : 42 fig. 68, 87, 92, 100, 290, 293, 297; Illies, 1966 : 235; Kis, 1974: 182-183 fig. 108.

Material : Alps : Isère. Normandy : Manche. Massif Central: Hérault, Puy-de-Dôme. Pyrenees : Pyrénées-Orientales, Ariège, Pyrénées-Atlantiques. Type locality : Burgdorf, Switzerland. Etymology : Named after M. Meyer who collected the first specimens of this species. Affinities : It is related to $P$. pyrenaica from which it can be easily separated by the shape of the male and female genitalia (compare Fig. 6 i-1 \& Fig. 8 a-d). Ecology : In France, it occurs in the foothill and lowland watercourses $(250-900 \mathrm{~m})$, up to $1100 \mathrm{~m}$ in the Pyrenees (Berthélemy 1966). In the Iberian Peninsula, it is much more orophilic and reaches higher altitudes up to $2700 \mathrm{~m}$ in the Sierra Nevada. It emerges in spring (II-V). Distribution : European species. In France, it occurs in the foothills of the main mountainous massifs (Alps, Jura, Vosges, Bretagne, Massif Central and Pyrenees).

Protonemura beatensis (Despax, 1929) (Fig. 7 a-d) (Fig. 11, arrow 4)

Nemoura beatensis Despax, 1929 : 90 fig. 11-14.

Protonemura beatensis - Berthélemy, 1960 : 52 fig. 8-15, 1963 : 275 fig. 1, 5, 10, 13, 16, 21, 22; Illies, $1966: 224$.

Material : Brittany : Finistère (Le Doare \& Manach leg.). Massif Central : Aude, Tarn. Pyrenees : PyrénéesOrientales, Ariège, Haute-Garonne, Pyrénées-Atlantiques. Type locality : Saint-Beat region, Haute-Garonne, Central Pyrenees, France. Etymology : It is named af- ter the village of Saint-Beat (Haute-Garonne), as the first specimen was collected in the surroundings of this village. Affinities : For many years it was confused with its sister species $P$. vandeli that often occurs at the same sites. The male can be distinguished by the shape of the paraproct's median lobe (Fig. 7 a, e) and by the shape of the epiproct (Fig. $7 \mathrm{~b}, \mathrm{f}$ ). The posterior edge of the female subgenital plate has two lateral rounded expansions covering the lobes (Fig. $7 \mathrm{~d}$ ), while it is about rectilinear in $P$. vandeli (Fig. $7 \mathrm{~h}$ ). P. beatensis is also a close relative of the Italian species $P$. robusta Berthélemy, 1963, inhabiting the northern Apennines. Ecology : Species occurring in various mountain brooks and rivers (340-2200 $\mathrm{m}$ ). The adults emerge in autumn (IX-XII). Distribution : It covers the Cantabrian Cordillera, Pyrenees, Massif Central and Brittany.

Protonemura vandeli Berthélemy, 1963 (Fig. 7 e-h)

Protonemura vandeli Berthélemy, 1963: 281 fig. 2, 7, 11, 15, 18-20, 23-26.

Material : Pyrenees : Pyrénées-Orientales, Haute-Garonne, Pyrénées-Atlantiques. Type locality : Espiaube stream, 1400 m a.s.l., Hautes-Pyrénées, France. Etymology : Named after A. Vandel, previous Directory of the Hydrobiology Laboratory of Toulouse. Affinities : Closely related to $P$. beatensis, with which it was confused by Despax (1951). The comparison of both species has been given previously. Ecology : Orophilic, stenothermous cold-water species, occurring in high altitude brooks and torrents $(800-2100 \mathrm{~m})$, up to $2400 \mathrm{~m}$ in the Spanish Pyrenees (Maladeta Massif, above «Trou du Toro», Esera 2400 m, 3 o", 14-X-89). It emerges in autumn (VIII-XI). Distribution : Pyrenean endemic.

Protonemura angelieri Berthélemy, 1963 (Fig. 7 i-1) (Fig. 12)

Nemoura (Protonemura) nimborella Despax, 1951 (nec Mosely, 1930): 68 fig. 27 d, e.

Protonemura angelieri Berthélemy, 1963: 284 fig. 3, 8, 12.

Protonemura angelieri - Illies, 1966: 223

Material : Pyrenees : Pyrénées-Atlantiques, Hautes-Pyrénées, Haute-Garonne, Ariège. Type locality : SaintBéat, 600 m a.s.l., Haute-Garonne, France. Etymology : Named after the French entomologist E. Angelier. Affinities : It is related to other autumnal species also occurring in the Pyrenees : P. beatensis, P. vandeli and $P$. montana, but the distinction from them is rather easy in both sexes. In fact, it is much closer to the alpine species $P$. algovia from which it differs by the shape of the paraproct's outer lobes (Fig. $7 \mathrm{j}, 9 \mathrm{j}$ ) and by the epi- 
Table 1. Distribution of the species recorded in France. Abbreviations: Alp = Alps; Jur = Jura; Vos = Vosges; Bre = Bretagne; C-M = Central Massif; Pyr = Pyrenees; Cor $=$ Corsica. ${ }^{*}=$ endemic species.

\begin{tabular}{|c|c|c|c|c|c|c|c|c|c|}
\hline & Species list & Alp & Jur & Vos & Bre & $\mathbf{C - M}$ & Pyr & Cor & European distribution \\
\hline$\overline{1}$ & algovia Mendl, 1968 & * & & & & & & & Alpine \\
\hline 2 & angelieri Berthélemy, 1963 & & & & & & * & & Central part of the Pyrenees \\
\hline 3 & ausonia padana ssp. $\mathrm{n}$. & $\bullet$ & & & & & & & West Alpine, North Apennine \\
\hline 4 & beatensis (Despax, 1929) & & & & - & - & $\bullet$ & & West France, North Spain \\
\hline 5 & brevistyla (Ris, 1902) & • & - & & & & & & Alps, Carpathes, Jura \\
\hline 6 & bucolica (Consiglio, 1957) & & & & & & & * & Corsican \\
\hline 7 & canigolensis Zwick \& Vinçon, 1993 & & & & & & * & & East Pyrenean \\
\hline 8 & caprai (Aubert, 1954) & - & & & & & & & West Alpine, North Apennine \\
\hline 9 & corsicana (Morton, 1930) & & & & & & & * & Corsican \\
\hline 10 & culmenis Zwick \& Vinçon, 1993 & & & & & & * & & East Pyrenean \\
\hline 11 & intricata intricata (Ris, 1902) & - & - & - & - & - & - & & Central South European \\
\hline 12 & lateralis (Pictet, 1836) & - & - & - & & & & & Central European \\
\hline 13 & meyeri (Pictet, 1841) & - & - & - & - & - & - & & European \\
\hline 14 & montana Kimmins, 1941 & & & - & & - & - & & Central North European \\
\hline 15 & nimborella Mosely, 1930 & * & & & & & & & Alpine \\
\hline 16 & nimborum (Ris, 1902) & - & - & - & & & & & Central European \\
\hline 17 & nitida (Pictet, 1835) & • & - & - & & - & & & Central European \\
\hline 18 & praecox praecox (Morton, 1894) & - & - & - & & - & - & & European \\
\hline 19 & pyrenaica Mosely, 1930 & & & & & & * & & Pyrenean, East Cantabrian \\
\hline 20 & risi (Jacobson \& Bianchi, 1905) & • & - & - & $\bullet$ & - & & & Central European \\
\hline 21 & spinulosa (Navás, 1921) & & & & & & - & & Pyrenean, North Spain \\
\hline 22 & tuberculata (Despax, 1929) & & & & & & $*$ & & Pyrenean \\
\hline 23 & vandeli Berthélemy, 1963 & & & & & & * & & Pyrenean \\
\hline 24 & vercingetorix Aubert, 1963 & & & & & * & & & French Central Massif \\
\hline 25 & zhiltzovae sp. $\mathrm{n}$. & & & & & & $*$ & & East Pyrenean \\
\hline & Total & 12 & 8 & 8 & 4 & 8 & 13 & 2 & \\
\hline & Micro-endemic species & 2 & 0 & 0 & 0 & 1 & 7 & 2 & \\
\hline & Micro-endemism rate (\%) & 17 & 0 & 0 & 0 & 13 & 54 & 100 & \\
\hline
\end{tabular}

proct that is about rectilinear in $P$. angelieri and curved in P. algovia (Fig. 7 k, 9 k). Ecology : This species inhabits montane brooks and torrents of moderate altitude $(600-1850 \mathrm{~m})$. The adults emerge in summer and autumn (VII-XI). Distribution : Micro-endemic species found in the central part of the Pyrenees (Fig. 12). It extends from the Ossau Valley (Pau tributary) up to the Orle Valley (Garonne tributary).

Protonemura pyrenaica Mosely, 1930 (Fig. 8 a-d)

Protonemura pyrenaica Mosely, 1930: 250 fig. 29-31.

Nemoura (Protonemura) pyrenaica - Despax, 1951: 65 fig. 26; Aubert, 1952: 250 fig. 7.

Protonemura pyrenaica - Illies, 1966: 240; Vinçon \& Pardo, 2004 (in this work $P$. asturica and $P$. pyrenaica are considered as two different species).
Material : Pyrenees : Pyrénées-Orientales, Ariège, Haute-Garonne, Hautes-Pyrénées, Pyrénées-Atlantiques. Type locality : French Pyrenees. Etymology : From Latin pirenaicus, inhabitant of the Pyrenees. Affinities : It is closely related to $P$. asturica that inhabits the northern Iberian Peninsula. Both species were separated in Vinçon \& Pardo (2004). Ecology : Eurytopic species occurring in various kinds of torrents and brooks between 300 and $2200 \mathrm{~m}$. Its highest locality is the Canigou Massif: Pyrénées-Orientales, Cady tributary, 2200 $\mathrm{m}, 2$ o, 8-VII-87. It has a long emergence period extending all over the year, except in winter (III-XII). Distribution : Pyrenees and eastern extremity of the Cantabrian Cordillera (Vinçon \& Pardo 2004).

Protonemura vercingetorix Aubert, 1963a (Fig. 8 eh) 

8.

Protonemura vercingetorix Aubert, 1963a: 223-125 fig. 1-

Material : Massif Central : Gard, Haute-Loire, Cantal, Puy-de-Dôme. Type locality : Chambon, 1000 m a.s.l., Puy-de-Dôme, France. Etymology : Named after the famous antique Gallic leader Vercingetorix. Affinities : Related to $P$. nimborum from which the male differs by the outer lobe of the paraprocts that is less enlarged apically (compare Fig. $8 \mathrm{f}$ and $8 \mathrm{j}$ ), and by the epiproct that is thinner in side view (compare Fig. $8 \mathrm{~g}$ and $8 \mathrm{k}$ ). The female differs by the subgenital plate hind margin regularly rounded in $P$. nimborum (Fig. 8 1) and slightly bilobed in $P$. vercingetorix (Fig. 8 h). Ecology : Orophilic and rheophilic species occurring in brooks of the montane zone (800-1200 m). Adults emerge in spring and summer (IV-VIII). Distribution : Endemic to the French Massif Central.

\section{Protonemura nimborum (Ris, 1902) (Fig. 8 i-1)}

Nemoura (Protonemura) nimborum Ris, 1902 : 389 fig. 910.

Nemoura (Protonemura) nimborum - Despax, 1952 : 66 fig. 27.

Protonemura nimborum - Illies, 1955: 47 fig. 34; Aubert, 1959 : 43 fig.72, 86, 90, 99; Illies, 1966 : 237; Kis, 1974 : 185-186 fig. 111.

Material : Alps : Haute-Savoie, Savoie, Isère, Drôme, Hautes-Alpes, Alpes-de-Haute-Provence, Alpes-Maritimes. Jura : Doubs. Type locality: Saint Gottard, Lepontine Alps, Switzerland. Etymology : From Latin nimbus = nimbus, storm clouds. Affinities : It is related to $P$. vercingetorix, P. nimborella and P. montana. Ecology : Rheophilic, Orophilic, and stenothermous cold-water species occurring in the torrents and brooks of the montane and sub-alpine zones $(800-2300 \mathrm{~m})$. Its higher locality in the French Alps is in the Queyras Massif, Hautes-Alpes, Valpreveyre, 2300 m, 2 o', 10 ㅇ, 3VI-91. It emerges in spring (III-VI). Distribution : Central European species extending from the Carpathians, throughout the Alpine Chain and northwards into Germany (Reusch \& Weinzierl 1999). It also occurs in the Vosges and Jura.

Protonemura nimborella Mosely, 1930 (Fig. 9 a-d)

Protonemura nimborella Mosely, 1930 : 250 fig. 32-33.

Nemoura (Protonemura) nimborella - Aubert, 1959: 43 fig. 74, 84, 97.

Protonemura nimborella - Illies, 1955 : 237; Aubert, 1959 : 43 fig. 73, 79, 97; Kis, 1974 : 187-188 fig. 112.

Material : Alps : Savoie, Isère, Hautes-Alpes, Alpes-deHaute-Provence, Alpes-Maritimes. Type locality : Genè- ve, Switzerland (Illies, 1966). Etymology : Name of uncertain derivation; it might be a diminutive derived from nimborum, because of the average smaller size of P. nimborella. Affinities : Related to P. nimborum and $P$. montana, from which it differs by the appendices of the paraprocts median lobe with several spines all along its length (Fig. 9 b) and by the shape of the epiproct. It is also related with the Pyrenean species, $P$. beatensis, $P$. angelieri and $P$. vandeli from which it differs by the shape of the outer and median lobes of the paraprocts and by the shape of the epiproct. Ecology : This strongly orophilic, stenothermous cold-water species, mainly occurs in high altitude brooks and torrents of the sub-alpine and alpine zones (1600-2600). The highest locality in the French Alps is Hautes-Alpes, Echalp, Guil tributary above Egourgeou lake, $2600 \mathrm{~m}$, 9 ơ, 2 ㅇ, 4-IX-88. In the Italian Alps it reaches 2750 m (Ravizza \& Ravizza Dematteis 1994). Adults emerge in autumn (IX-XI). Distribution: Strictly endemic to the Alps.

Protonemura montana Kimmins, 1941 (Fig. 9 e-h) (Fig. 11, arrow 1)

Protonemura montana Kimmins, 1941 : 90 fig. 13, 14.

Protonemura montana - Illies 1966 : 236; Kis 1974 fig. 113.

Material : Massif Central : Puy-de-Dôme, Pyrenees : Pyrénées-Orientales. Type locality : Ridal Beck, Westmorland, England. Etymology: From Latin montanus $=$ inhabiting the mountains. Affinities : Close both to the Pyrenean $P$. angelieri and $P$. vandeli, and to the alpine $P$. algovia and $P$. nimborella. It differs from $P$. angelieri, $P$. vandeli and $P$. algovia by the shape of the paraproct's outer lobe (compare Fig. 9 f with Fig. 7 f, Fig. $7 \mathrm{j}$ and Fig. 9 j); and from P. nimborella by the shape of the epiproct (compare Fig. $9 \mathrm{~g}$ and Fig. 9 c). Ecology : Orophilic, stenothermous cold-water species, occurring in small brooks of the montane and sub-alpine zone (1000-2250 m). The emergence period is chiefly in summer and autumn (VII-IX), but in the Oriental Pyrenees one male was captured in May. Distribution : Central North European species from the Carpathians, German Black Forest, Vosges, Massif Central and Oriental Pyrenees that constitute its southern limit. It does not occur in the Alps.

Protonemura algovia Mendl, 1968 (Fig. 9 i-1) (Fig. 13)

Protonemura algovia Mendl, 1968 : 249-252 fig. 1-5.

Protonemura algovia - Ravizza \& Ravizza Dematteis, 1981 : 151-156 fig. 2.

Material : Alps : Savoie, Isère (Gay 1982a). Hautes- 
Alpes (Vinçon 1996). Italy : Cottian Alps: Agnel Pass, Casteldelfino, Varaita trib., 2200 m, 1 \&, 26-IX-88; above Sta Anna, Varaita di Bellino, 1900 m, 1 ơ, 27-IX-88. Type locality : Oyal, $1100 \mathrm{~m}$ a.s.l., Traufbach valley, Algovian Alps, Germany. Etymology : From Algovia (Allgäu), a southern German region that comprises a small portion of the northern slopes of the eastern Alps. Affinities : Closely related to the Pyrenean species $P$. angelieri, $P$. vandeli and $P$. beatensis from which it mainly differs by the thinner expansion of the paraproct's median lobe and by the shape of the paraproct's outer lobe (compare Fig. 9 j and Fig. 7 b, 7 f, 7 $\mathrm{j})$. The females are clearly different. It is also closely related to $P$. montana from which it clearly differs by the shape of the paraproct's outer lobe (compare Fig. 9 $\mathrm{j}$ and Fig. $9 \mathrm{f}$ ). It resembles also the sympatric alpine species $P$. nimborella, from which the males are easy to separate, but the females could be confounded and should be confirmed by the capture of males. Ecology : Rheophilic and orophilic species occurring in high altitude mountain brooks and torrents (1100$2200 \mathrm{~m}$ ). Adults emerge in autumn (IX-XI). Distribution : It has a rather wide distribution area throughout the Alpine Chain, from France to Austria, but it is always very scarce and therefore its distribution seams to be discontinuous (Fig. 13). In the French Alps it is mainly localized near the Italian border. It is also recorded from Switzerland: Valais and Tessin (Zwick 1971, Aubert \& al. 1996), Italy: Cottian Alps and Lombardy (Ravizza \& Ravizza Dematteis 1981), Germany: Bavaria, Algaw (Mendl 1968a) and Austria (Mendl 1968b, Theischinger 1976).

\section{Key to males}

1 Ventral sclerite of epiproct covered with spines all along its length. Sclerotized stem of paraprocts reduced to a short minute thin spine.

1) Ventral sclerite of epiproct only partially covered with spines. Sclerotized stem of paraprocts stronger and of different length.

2 (1') Ventral sclerite of epiproct provided with a strong protuberance in its distal third (tuberculata group).

praecox

Ventral sclerite of epiproct without strong protuberance or at the most with a feeble protrusion.

3 (2) Ventral protuberance divided into two parts when seen by the apex of the epiproct (Figs $2 \mathrm{k}-\mathrm{p}$ ).

ausonia padana

3' Ventral protuberance undivided.
4 (3') Sclerotized stem of the paraproct's median lobe thin and blade shaped. Epiproct elongate with its protuberance of moderate size (Figs 2 a-e).

4. Sclerotized stem of the paraproct's median lobe much larger, regularly shortening towards the apex and ending into a small hook. Epiproct massive with a very strong protuberance (Figs $2 \mathrm{f}-\mathrm{j}$ ).

tuberculata

5 (2') Epiproct with a distinct slender process arising from the centre of its tip (corsicana group).

5. Epiproct without any process arising from the tip.

6 (5) Terminal process of the epiproct like a comma-shaped filament. Sclerotized stem of the paraproct's median lobe straight (Figs 3 a-e).

canigolensis

6' Terminal process of the epiproct straight.

7 (6') Terminal process of the epiproct long. Sclerotized stem of the paraproct's median lobe gently curved outwards (Figs $3 \mathrm{f}-\mathrm{j}$ ).

corsicana

7. Terminal process of the epiproct short. Sclerotized stem of the paraproct's median of different shape lobe lacking (Figs 3 k-o).

bucolica

8 (5') Median lobe with a short stem, about as long as its base.

9 (8) Dorsal sclerite of the epiproct forked anteriorly in side view. Sclerite of the paraproct's outer lobe without any apical spines (risi group).

9' Dorsal sclerite of the epiproct not forked in side view. Sclerite of the paraproct's outer lobe with one or several apical spines.

10 (9) Base of the paraproct's median lobe about globular. Paraproct's outer lobe with a thin sclerotized lateral branch (Fig. 4 i-l).

10' Base of the paraproct's median lobe longer than large. Paraproct's outer lobe without any lateral branch (Fig. 4 e-h).

11 (9') Epiproct widening progressively towards the apex, in side view (Figs 5 k, 5 o). 
11 Epiproct not widening progressively towards the apex. Tip of the epiproct strongly curved upward (Fig. 5 g). One strong spine at the tip of the paraproct's outer lobe sclerite (Figs 5 e-h).

12 (11) Sclerite of the paraproct's outer lobe with 1 (exceptionally 2) apical spines. A tiny expansion raises upward at the tip of the epiproct (Figs. 5 i-1).

zhiltzovae sp. $n$.

12' Sclerite of the paraproct's outer lobe with 5 to 6 apical spines. No expansion at the tip of the epiproct (Figs. $5 \mathrm{~m}$-p).

13 (8') Epiproct with a small preapical expansion, in side view (Fig. 5 c). Tip of the outer lobe rounded with 3 or 4 spines (Figs 5 a-d).

13 Epiproct without any preapical expansion.

14 (13') Stem of the median lobe with few scattered spines along its length

14. Stem of the median lobe with only one apical spine

15 (14) Outer lobe sclerite covered with numerous spines near the tip (Fig. 9 a-d).

15. Outer lobe sclerite without spines at the tip (Fig. 8 a-d).

16 (14') Outer lobe sclerite with a preapical elbow (Figs 8 j, 9 f).

16' Outer lobe sclerite without any preapical elbow.

17 (16) Tip of the outer lobe with a deep hollow (Fig. $8 \mathrm{j}$ ).

17 Tip of the outer lobe without any hollow (Fig. $9 \mathrm{f}$ ).

18 (16') Outer lobe sclerite with a regular series of long spines along its terminal half (Fig. 9 i-1).

18 Outer lobe sclerite without a regular series of long spines along its terminal half

19 (18') Tip of the outer lobe sclerite enlarged and covered with a row of spines (Figs $6 \mathrm{~b}, 6 \mathrm{f}, 8 \mathrm{f})$.

19' Tip of the outer lobe sclerite not covered with a row of spines

20 (19) Stem of the median lobe narrowing progressively from the base toward the tip (Fig. 6 e-h).

nitida
20' Stem of the median lobe slender, not narrowing progressively from the base toward the tip

21 (20') Tip of the epiproct strongly bent upward. Stem of the median lobe straight (Figs 6 a-d).

caprai

21 Tip of the epiproct slightly bent upward. Stem of the median lobe curved outwards before the tip (Figs $8 \mathrm{e}-\mathrm{h}$ ). vercingetorix

22 (19') Outer lobe strong and widening towards its tip; its membranous field well developed and bilobed (Figs 6 i-l).

meyeri

22' Outer lobe slender and not widening towards its tip; its membranous field poorly developed and not bilobed (Figs $7 \mathrm{~b}, \mathrm{f}, \mathrm{j})$.

23 (22') Tip of the epiproct strongly bent upward (Figs 7 a-d).

beatensis

23 Tip of the epiproct not bent upwards.

24 (23') Epiproct bent downwards before the tip. Stem of the median lobe curved inwards at the tip (Figs $7 \mathrm{e}-\mathrm{h}$ ).

vandeli

24, Epiproct about rectilinear. Stem of the median lobe gently curved outwards from the base towards the tip (Figs $7 \mathrm{i}$ $1)$.

angelieri

\section{Key to females}

The characters that could be used to identify the females are poor and often difficult to study because they are rather variable and sometimes they depend of the state of preservation of the specimens. For example, the gills could be contracted or the subgenital plate could be deformed during mating. Therefore, it is often very difficult to separate closely related species (P. lateralis and P. caprai, for example) and we recommend confirming the presence of a species in a region by the capture of males.

algovia $\quad 1 \quad$ Cervical gills long, much longer than the diameter of an eye. One or two preapical constrictions (Fig. 10 a).

19 1' Cervical gills of medium size or short, about as long as the diameter of an eye or shorter. Pre-apical constriction wan20 ting or just a little perceptible (Fig. 10 b).

2 (1) Two lateral expansions on the subgenital plate posterior edge (Figs $7 \mathrm{~d}, 7$ 1).

2' No lateral expansions on the subgenital lateralis plate posterior edge. 
3 (2) Subgenital plate large (2/3 of the segment's width). Lateral expansions large and poorly extending backwards. Vaginal lobes mostly hidden by the subgenital plate. Pregenital plate well developed on sternite 7 (Fig. 7 d).

Subgenital plate narrow (half the segment's width). Lateral expansions narrow and strongly extending backwards. Vaginal lobes well visible on each side of the subgenital plate. Pregenital plate hardly visible on sternite 7 (Fig. 7 1).

4 (2') Posterior edge of the subgenital plate sinuous, often forming three lobes. A deep depression in the middle of the subgenital plate. Vaginal lobes extending beyond the posterior edge of the plate (Fig. 5 h)

beatensis

11 Posterior edge of the subgenital plate not tongue-shaped.

12 (11) Pregenital plate well pigmented on sternite 7.

12' Pregenital plate wanting on sternite 7 (Fig. $2 \mathrm{j}$ ).

tuberculata

angelieri $13(12)$ Cervical gills of medium size with slightly visible apical constrictions (Fig. 5 p).

brevistyla

13. Cervical gills very short without apical constrictions (Fig. 2 e).

culmenis

14 (11') Posterior edge of the subgenital plate convex (Figs 2 p, 4 1, 6 d, 6 h).

14. Posterior edge of the subgenital plate sub-rectilinear or bilobed.

15 (14) Vaginal lobes well developed on each posterior corner of the plate (Figs 2 p, 4 1).

15. Vaginal lobes hardly visible on each posterior corner of the plate (Figs $6 \mathrm{~d}, 6$ h).

caprai lateralis

16 (15) Subgenital plate lips-shaped. Pregenital plate well marked on sternite 7 (Fig. 2 p).

ausonia padana

16 Subgenital plate sub-trapezoidal. Pregenital plate wanting on sternite 7 (Fig. $41)$.

spinulosa

17 (14') Posterior edge of the subgenital plate sub-rectilinear (Figs 5 d, 5 1, 9 d).

17. Posterior edge of the subgenital plate bilobed.

20 rior corners of the plate. Paraprocts rounded posteriorly (Fig. 4 d).

praecox

8, Vaginal lobes extending behind the posterior edge of the plate. Paraprocts pointed posteriorly (Fig. 6 l).

meyeri

18 (17) Well developed and strongly sclerotized pregenital plate on sternite 7 (Fig. 5 d).

intricata

18' Pregenital plate hardly visible on sternite 7. Cervical gills of medium size with slightly visible apical constrictions.

nimborum

19 (18') Vaginal lobes almost completely hidden under the subgenital plate (Fig. 9 d).

19' Vaginal lobes clearly visible on each side of the subgenital plate (Fig. 5 1). zhiltzovae sp. $\boldsymbol{n}$.

pyrenaica

20 (17') The two lobes of the subgenital plate separated by a narrow space (Figs 3 e, 3 j). 
20' The two lobes of the subgenital plate separated by a wide space (Figs 3 o, 4 h).

21 (20) Pregenital plate well marked on sternite 7 (Fig. 3 j).

corsicana

21' Pregenital plate hardly visible on sternite 7 (Fig. 3 e).

canigolensis

22 (20') Subgenital plate sub-triangular shaped, with a less pigmented median area. $\mathrm{Pa}$ raprocts rounded posteriorly (Fig. $4 \mathrm{~h}$ ).

risi

22'

Subgenital plate lips-shaped. Paraprocts slightly pointed posteriorly (Fig. 3 o).

bucolica

\section{Types of distribution}

Among the 25 Protonemura species occurring in France, we can distinguish the following groups (cf Aubert 1963c, 1963d).

- Holoeuropean species (2 species) : P. meyeri and $P$. praecox praecox. Both are widespread in France, but the latter, being more orophilic, has not been reported from Brittany.

- Central North European species (1 species) : $P$. montana. This orophilic species does not occur in the Alps; westwards, it extends into the Vosges, Massif Central and eastern part of the Pyrenees that constitutes its southern limit (Fig. 11, arrow 1). Its distribution is similar to that of Leuctra digitata.

- Central South European species (1 species) : $P$. intricata. Widespread in France.

- Central European species (5 species) : They are mainly Alpino-Carpathian species. According to their extension into France, we can distinguish four subgroups : - P. brevistyla : French Alps and Jura (Fig. 11, arrow 2); - P. lateralis and P. nimborum : French Alps, Jura and Vosges (Fig. 11, arrow 3); - P. nitida : French Alps, Jura, Vosges and Massif Central; - P. risi : French Alps, Jura, Vosges, Massif Central and Brittany.

- West European species (2 species) : They are also called «Espèces Pyrénéennes extensives» (Aubert 1963c). They occur in the whole Pyrenean chain and extend into northern Spain or western France : - P. spinulosa occurs in the Pyrenean chain and northern Spain (Cantabrian Cordillera, Demanda, Cameros). Its distribution is similar to that of Nemoura moselyi, $N$. pseudoerratica and Leuctra lamellosa lamellosa (Vinçon \& Pardo 2004); - P. beatensis extends from northern Spain up to the Massif Central and Brittany (Fig. 11, arrow 4). Three other Pyrenean species have a si- milar distribution : Leuctra despaxi, L. castillana and Isoperla acicularis, but they are limited northwards to the Massif Central.

- Italian elements occurring in the French Maritime Alps (2 species) : P. caprai and $P$. ausonia padana (Fig. 13).

- Endemic species (12 species) : - French Alps : $P$. nimborella and P. algovia; - Massif Central : P. vercingetorix; - Pyrenees : P. angelieri, P. canigolensis, $P$. culmenis, $P$. pyrenaica, $P$. tuberculata, $P$. vandeli and P. zhiltzovae; - Corsica : P. bucolica and P. corsicana. Their distribution is commented in the following paragraphs.

\section{Distribution by regions}

The Protonemura distribution in the main French mountainous regions is presented in Table 1. The studies synthesized in this table are the following : French Alps : Aubert 1986, Gay 1982a, 1982b, Vinçon 1996, Jura Massif : Verneaux 1973, Vosges Massif : Aubert 1963b, Massif Central : Aubert 1963d, Berthélemy 1965, Berthélemy \& Laur 1975, Pyrenees : Berthélemy 1960, 1963, 1966, Vinçon 1987, Zwick \& Vinçon 1993, Vinçon \& Pardo 2004, all France : Despax 1951. The distribution data of these studies are complemented with our own collections data.

In mainland France, diversity decreases from South to North: Pyrenees (13 species), Alps (12), Jura (8), Massif Central (8), Vosges (8) and Brittany (4).

During the Pleistocene Ice Age when northern and Central Europe were covered by ice, species occurring in the Alps or Pyrenees survived on the southern slopes of these massifs at lower latitudes and with the influence of the Mediterranean Sea. Afterwards, with the retreat of the glaciers, species mainly living in the foothills or eurytopic elements could extend northwards to the rest of Europe : P. intricata, $P$. meyeri, $P$. nitida, $P$. praecox and $P$. risi.

The more orophilic Alpino-Carpathian species have also partly succeeded in extending northwards, but their distribution remains more restricted : - P. brevistyla up to the Jura, - P. lateralis and P. nimborum up to the Jura and Vosges. The north Iberian species $P$. beatensis has also extended northwards from the Pyrenees into the Massif Central and Brittany. Nevertheless, some of the mostly orophilic Alpine or Pyrenean species remain strictly endemic (see following paragraphs).

\section{Pyrenees}

Among the Protonemura species widespread in Europe, only four have colonized the Pyrenees : P. intri- 
cata intricata, $P$. meyeri, $P$. montana and $P$. praecox praecox. The widespread species $P$. risi is replaced by its sister species $P$. spinulosa that occupies the northwestern Iberian Peninsula.

The Pyrenean Protonemura communities are therefore characterized by a high degree of endemism (54 $\%)$. The 7 endemic species are strongly orophilic, which could explain their isolation : P. culmenis (2000$2700 \mathrm{~m})$, P. zhiltzovae (1900-2250 m), P. tuberculata (1300-2550 m), P. vandeli $(800-2400 \mathrm{~m})$, P. canigolensis $(600-2150 \mathrm{~m})$, P. angelieri $(600-1850 \mathrm{~m})$ and $P$. pyrenaica $(300-2200 \mathrm{~m})$. Among them, four could be considered micro-endemic species since they are localized in a restricted mountainous area within the Pyrenees, from east to west : $P$. canigolensis, $P$. culmenis, $P$. zhiltzovae and P. angelieri (Fig. 12).

Pyrenean endemism also occurs in other stonefly families, especially the Leuctridae with 13 species (Vinçon \& Ravizza 2001). The isolation is more important on the northern slope of the chain that is directly submitted to the Atlantic influence. In these humid places, the crenophilous species are often shortwinged (Protonemura zhiltzovae, Capnioneura brachyptera, Leuctra zwicki and L. joani) or even apterous (Capnioneura aptera and Leuctra clerguae), increasing their isolation (Vinçon \& Ravizza 2000, 2001, Vinçon \& Sanchez-Ortega 2002).

\section{Massif Central}

The Massif Central fauna is influenced by its position at the crossroads between the Alps, the Jura and the Pyrenees (Fig. 11).

Most Protonemura species occurring in this massif $(75 \%)$ are widespread in Europe : $P$. intricata, $P$. meyeri, $P$. montana, $P$. nitida, $P$. praecox and $P$. risi. For these species, the main migration way between the Massif Central and the rest of Europe is following the western edge of the Saône Valley (Morvan, Bourgogne, Langre Plateau, Vosges) and then crossing the Rhenan depression and the German Black Forest (Berthélemy 1965) (Fig. 11, arrow 1).

On the contrary, the wide valleys of the Rhône and Saône Rivers constitute an efficient ecological barrier for orophilic species such as $P$. brevistyla, $P$. lateralis and $P$. nimborum that reach the Jura or Vosges Massifs but not occur in the Massif Central (Aubert 1963d).

On the southern edge of the Massif Central, the Garonne and Aude Valleys (Carcassonne depression) also constitute an efficient barrier for the numerous Pyrenean endemic species (Berthélemy 1965). Nevertheless, this ecological barrier is less efficient than the Rhône and Saône Valleys, since few elements occur- ring in the Massif Central have a Pyrenean origin (Protonemura beatensis, Leuctra despaxi, L. castillana and Isoperla acicularis) and since strongly orophilic European stoneflies have also succeeded to cross this depression (Protonemura montana, Perlodes intricatus, Capnia vidua, ...) (Fig. 11, arrows 1).

Orophilic isolation is rather poor in the Massif Central, with only three endemic species and one Protonemura : P. vercingetorix, Isoperla ambigua and Leuctra flavomaculata. Therefore, the rate of endemism in the whole stonefly family is much lower in the Massif Central $(5 \%)$ than in the Pyrenees (24\%), probably due to the lesser altitudes (Massif Central: $1885 \mathrm{~m}$, Pyrenees: $3404 \mathrm{~m}$ ) and to the influence of the Pleistocene glaciations.

\section{Alps}

In contrast to the Pyrenees where the species richness is mainly due to a high rate of endemism, the richness of the French Alps is due both to the presence of numerous species widespread in Europe (P. brevistyla, $P$. intricata intricata, $P$. lateralis, $P$. meyeri, $P$. nimborum, $P$. nitida, $P$. praecox praecox and $P$. risi) and to the presence of Italian elements that occur only in the French Maritime Alps close to the Italian border : $P$. caprai and P. ausonia padana (Fig. 13).

Of course, there are several endemic Protonemura species in the whole Alpine Massif, but only two extend as far as the French Alps : P. nimborella and P. algovia. The former is frequent and has a continuous distribution all along the chain while the latter is always very scarce and seems to be limited to few scattered localities (Fig. 13).

\section{Jura and Vosges}

The Protonemura fauna of these two neighbouring massifs is rather similar, also resembling the alpine fauna. Nevertheless, the Vosges fauna is characterized by several Central North European species occurring in the German Black Forest but not present in the Jura and western Alps : Protonemura montana, Leuctra digitata, Diura bicaudata, Arcynopteryx compacta, Isoperla goertzi, Siphonoperla neglecta. Indeed the Vosges and Black Forest stonefly fauna are very similar, despite the Rhenan depression (Aubert 1963b).

\section{Brittany}

The fauna of Brittany is mainly a subset of the Massif Central fauna, with the presence of both widely distributed species ( $P$. intricata intricata, $P$. meyeri, $P$. risi) together with a western European element, $P$. beatensis (Fig. 11, arrow 4). 


\section{Corsica}

Among the 12 Corsican stoneflies, two belong to the Protonemura genus : P. corsicana Morton, 1930 and $P$. bucolica Consiglio, 1957. They are both Corsican endemic species belonging to the corsicana group that has mainly a circum-Mediterranean distribution. This group also extends to the Black Sea and Caspian regions (Vinçon \& Zhiltzova 2004).

\section{Comparison with the neighbouring mas- sifs}

\section{The Pyrenees compared to the Cantabrian Cor- dillera and Galicia}

The Pyrenean richness in endemic species can be compared to that of the Cantabrian Cordillera and Galicia. Indeed in this huge chain extending westwards from the Pyrenees three endemic Protonemura species occur (Vinçon \& Ravizza 1998), together with 12 other endemic stonefly species (Vinçon \& Pardo 2004). As in the Pyrenees, the great richness of this mountainous region is mainly due to the humid Atlantic influence that favours crenophilic and orophilic isolation. Here also, the isolation is increased by a tendency for shortwingedness ( 5 brachyperous and 1 apterous taxa : Leuctra wilmae, L. microstyla saja, L. microstyla microstyla, L. microstyla nalon, L. besucheti and Capnioneura narcea).

\section{The Alps compared to the Apennines and Sicily}

The genus Protonemura appears much more diversified in the Apennines than in the Alps. Indeed, 13 endemic species display a succession from North to South in the Apennine Chain and its continuation into Sicily : $P$. tyrrhena, $P$. elisabethae, $P$. robusta, $P$. ausonia ausonia, $P$. salfii, $P$. costai, $P$. hirpina, $P$. macrura, $P$. italica, P. lagrecai, $P$. consiglioi, $P$. sicula and $P$. helenae (Consiglio 1979, Nicolai 1985). On the other hand, in the whole Alpine Chain only four endemic Protonemura species occur : P. nimborella, P. algovia, P. bipartita and P. julia.

Contrary to Protonemura, endemism in the Leuctra genus is much more important in the Alps with 25 species (Ravizza \& Vinçon 1998, 2003) compared to the Apennines and Sicily with only four endemic species : L. costai, L. silana, L. archimedis and L. concii (the last one also estends to the Maritime Alps) (Consiglio 1979, Vinçon 1996).

The remarkable difference in the composition of the Protonemura and Leuctra communities in the Alps and Apennines could be due to zoogeographical reasons and climatic preferences. The Leuctra species have a preference for the more humid regions such as the western Alps, western Pyrenees, Cantabrian Cordillera, Galicia, Turkish Pontique chain (Ravizza \& Vinçon 1998, Vinçon \& Ravizza 2001, Vinçon \& Sivec 2001, Vinçon \& Pardo 2004), the genus Protonemura is more diversified in drier mountainous regions such as the Apennines or the western Turkish coast (Consiglio 1979, Vinçon \& Zhiltzova 2004).

\section{Acknowledgements}

We dedicate this work to our colleague and mentor Claude Berthélemy who made a major contribution to our knowledge of the French Protonemura. We are very grateful to Dr. Giovanni Delmastro (Carmagnola) and Dr. Romolo Fochetti for their loan of valuable material. We thank Prof. J. Brittain and J. P. Reding for reviewing the text.

\section{References}

Angelier E. 1958. - Les eaux douces de Corse et leur peuplement. Vie et Milieu Suppl. (Paris), 8, 1-56.

Aubert J. 1952. - Plécoptères récoltés par Mr. F. SCHMID en Espagne. Eos, Rev. Esp. Ent. (Madrid), 28, 249-270.

Aubert J. 1953. - Plécoptères européens nouveaux. Mitt. Schweiz. ent. Ges., 26, 72-76.

Aubert J. 1954a. - Quelques Nemouridae espagnols nouveaux. Mitt. Schweiz. ent. Ges., 27, 115-136.

Aubert J. 1954b. - Note sur quelques Plécoptères du Piémont et de Ligurie avec la description de deux espèces nouvelles. Boll. Soc. ent. ital., 84, 107-113.

Aubert J. 1956a. - Contribution à l'étude des Plécoptères d'Espagne. Mém. Soc. Vaudoise Sci. Nat., 11, 209-276.

Aubert J. 1956b. - Contribution à l'étude des Plécoptères d'Afrique du Nord. Mitt. Schweiz. ent. Ges., 29, 419-436.

Aubert J. 1959. - Plecoptera. Insecta Helvetica, Fauna, 1, 1-140.

Aubert J. 1963a. - Deux Protonemura nouvelles de France et d'Espagne. Mitt. Schweiz. Ent. Ges., 36, 123-126.

Aubert J. 1963b. - Les Plécoptères des Vosges. Le Hohneck, Strasbourg, 287-292.

Aubert J. 1963c. - Les Plécoptères de la Péninsule Ibérique. EOS Rev. Espan. Entomol., 39, 23-107.

Aubert J. 1963d. - Les Plécoptères du Massif Central. Bull. Soc. ent. France, 68, 163-185.

Aubert J. 1986. - Les Plécoptères des Alpes Françaises. Annls Soc. ent. Fr. (N.S.), 22, 81-104.

Aubert J., Aubert C.E., Ravizza C. \& Ravizza Dematteis E. 1996. Les Plécoptères du canton du Tessin, des vals de Mesolcina et de Valanca (canton des Grisons). Mitt. Schweiz. ent. Ges., 69, 9-40.

Baumann R.W. 1975. - Revision of the stonefly family Nemouridae (Plecoptera): a study of the world fauna at the generic level. Smiths. Contribs Zool. (Washington D.C.), 211, 1-74.

Berthélemy C. 1960. - Note sur quelques Nemouridae (Plécoptères) du sud-ouest de la France. Bull. Soc. Zool. France (Paris), 85, 5258.

Berthélemy C. 1963. - Les Protonemura (Plécoptères) automnales des Pyrénées. Bull. Soc. Hist. Nat. Toulouse, 98, 275-286

Berthélemy C. 1965. - Note faunistique sur les Plécoptères du Massif Central. Ann. Limnol., 2, 221-237.

Berthélemy C. 1966. - Recherches écologiques et biogéographiques sur les Plécoptères et Coléoptères d'eau courante (Hydraena et Elminthidae) des Pyrénées. Ann. Limnol., 2, 227-458.

Berthélemy C. 1981. - On two endemic Protonemura from the Pyre- 
nees (Plecoptera : Nemouridae). Ann. Limnol., 17, 243-249.

Berthélemy C. \& Laur C. 1975. - Plécoptères et Coléoptères aquatiques du Lot (Massif Central Français). Ann. Limnol., 11, 263285.

Consiglio C. 1955. - Due Nuove specie dei Plecotteri Italiani. Boll. Soc. Ent. Ital. (Genova), 85, 70-77.

Consiglio C. 1957a. - Contributo alla conoscenza dei Plecotteri di Sardegna. Mem. Soc. Ent. Ital. (Genova), 36, 31-44.

Consiglio C. 1957b. - Contributo alla conoscenza dei Plecotteri di Corsica. Mem. Soc. Ent. Ital. (Genova), 36, 121-135.

Consiglio C. 1958. - Contributo alla conoscenza dei Plecotteri olognati dell'Italia centrale. Mem. Soc. Ent. Ital. (Genova), 37, 117131.

Consiglio C. 1979. - La distribuzione dei Plecotteri italiani. Lavori Soc. It. Biogeogr. (n. s.), 6 (1976), 383-393.

Despax R. 1929. - Plécoptères pyrénéens. I. Étude et description de quelques formes du genre Nemoura Latr. Bull. Soc. Hist. Nat. Toulouse, 58, 77-104.

Despax R. 1951. - Plécoptères. Faune de France, Lechevalier (Paris), 55, 1-280.

Fochetti R. \& Nicolai P. 1988. - I Plecotteri dell'alta valle del Fiume Tenna (Monte Sibillini, Italia centrale (Plecoptera). Boll. Ass. Romana Entomol., 42 (1987), 9-18.

Fochetti R. \& Nicolai P. 1996. - Emergence patterns of Plecoptera in an Apenninic Stream (Central Italy). Boll. Soc. ent. Ital. (Genova), 128, 111-124.

Gay C. 1982a. - Les communautés benthiques d'un torrent des Alpes françaises : l'Eau d'Olle (Isère). Trav. Lab. Hydrobiol. Grenoble, 7-31.

Gay C. 1982b. - La faune benthique d'un torrent des Alpes françaises : la Romanche au Plan de l'Alpe (Hautes-Alpes). Trav. Lab. Hydrobiol. Grenoble, 33-44.

Hynes H.B.N. 1977. - A key to the adults and nymphs of the British stoneflies (Plecoptera) with notes on their ecology and distribution. Freshwat. Biol. Ass. Sci. Publ. (Ambleside), 17, 1-92.

Illies J. 1955. - Steinfliegen oder Plecoptera. Die Tierwelt Deutschlands und der angrenzenden Meeresteile, Jena, 43, 1-150.

Illies J. 1966. - Katalog der rezenten Plecoptera. Das Tierreich, Walter de Gruyter \& co (Berlin), 82, 1-632.

Jacobson G.G.. \& Bianchi V.L. 1905. - Prjamokrylyje, etc. The Orthoptera and Pseudoneuroptera of Russia, 1-952.

Kempny P. 1898. - Zur Kenntnis der Plecopteren. I. Über Nemura Latr. Verh. zool. bot. Ges. Wien, 48, 37-68.

Kimmins D.E. 1940. - A synopsis of the British Nemouridae (Plecoptera). Trans. Soc. Brit. Ent. (Southampton), 7, 65-83.

Kimmins D.E. 1941. - A new species of Nemouridae (Plecoptera). $J$. Soc. Brit. Ent. (Southampton), 2, 89-93

Kis B. 1974. - Plecoptera. Fauna Rep. Soc. Romania, Insecta. Acad. Rep. Soc. Romania, 8, 1-273.

Klapálek F. 1905. - Conspectus Plecopterorum Bohemiae. Cas. ceské Spol. ent. (Praha), 2, 27-32.

Lavandier P. 1979. - Ecologie d'un torrent Pyrénéen de haute montagne, l'Estaragne. Thèse de Docteur d'Etat, Toulouse, 532 p.

Lillehammer A. 1974. - Norwegian stoneflies I. Analyses of the variations in morphological and structural characters used in taxonomy. Norsk ent. Tidsskr., $21: 59-107$.

Lillehammer A. 1988. - Stoneflies (Plecoptera) of Fennoscandia and Denmark. Fauna ent. scand., 21, 1-165.

Mendl H. 1968a. - Eine neue Plecoptere aus dem Allgäuer Alpen. Mitt. Schweiz. ent. Ges., 49, 249-252.

Mendl H. 1968b. - Plecoptera aus Österreich. Gewass. Abwass., 47 61-73.

Mosely M.E. 1930. - Plecoptera. In : New European Trichoptera and Plecoptera. Trans. Ent. Soc. (London), 78, 249-253.

Morton K.J. 1894 - XXIII. Palearctic Nemourae. Trans. Ent. Soc.
(London), 557-574

Morton K.J. 1930. - Plecoptera collected in Corsica by Mr. Martin E. Mosely. Entomologist's monthl. Mag. (London), 66, 75-81.

Navás L. 1921. - Plecópteros. In : Insectos nuevos de la Peninsula lbérica. Brotéria, Sér. Zool. (Lisboa), 19, 73-75.

Newman E. 1853. - Art. xxix : Proposed Division of Neuroptera, into two Classes. Zoologist (London), 11, 82-204.

Nicolai P. 1985. - On the Evolution and Biogeography of the Protonemura species of the corsicana Group, with the description of $P$. helenae sp. $\mathrm{n}$. from Sicily (Plecoptera, Nemouridae). Aquatic Insects, 4, 249-257.

Nicolai P. \& Fochetti R. 1983 - La fauna a Plecotteri di un sistema reocrenico di alta qualità : il tratto sorgivo del T. Cosa. Rivista di Idrobiologia, 22, 187-202.

Pictet F.J. 1835. - Description de quelques nouvelles espèces d'insectes du Bassin du Léman. Némoures. Mém. Soc. Phys. Hist nat. Genève (1836), 7, 173-190.

Pictet F.J. 1841. - Histoire naturelle générale et particulière des insectes Névroptères. Famille des Perlides. 1 partie., 1-423

Ravizza C. 1974. - Ricerche ecologico-faunistiche sui Plecotteri della valle Staffora (Appennino Lombardo) (plecoptera). Boll. $\mathrm{Mu}$ seo civ. St. Nat. Verona, 1, 195-248.

Ravizza C. 1976. - Ricerche ecologico-faunistiche sui Plecotteri del torrente Erro (Appennino Ligure) (Plecoptera). Boll. Museo civ. St. Nat. Verona, 3, 331-361.

Ravizza C. \& Ravizza-Dematteis E. 1978. - Mountain brooklet Stonefly-fauna of Northern Apennines (Plecoptera). Atti Soc. ital. Sci. nat., 119, 229-242.

Ravizza C. \& Ravizza-Dematteis E. 1979. - I Plecotteri del corso medio-inferiore del torrente Nure (Appennino piacentino) (Plecoptera). Natura, 70, 193-217.

Ravizza C. \& Ravizza-Dematteis E. 1981. - Protonemura algovia Mendl, nuova per 1'Italia, nelle Alpi Retiche (Plecoptera, Nemouridae). Atti Soc. ital. Sci. nat., 122, 151-156.

Ravizza C. \& Ravizza-Dematteis E. 1988. - Les Plécoptères de la vallée supérieure du Pô (Alpes Cottiennes). Notes faunistiques et écologiques. Annal. Limnol., 24, 243-260.

Ravizza C. \& Ravizza-Dematteis E. 1994. - Note sur les Plécoptères rhéophiles de quelques biotopes lotiques de haute altitude du versant interne des Alpes centrales et occidentales. Boll. Zool. Agr. Bachic. Ser. II, 26, 183-199.

Ravizza C. \& Vinçon G. 1998. - Les Leuctridés (Plecoptera, Leuctridae) des Alpes. Mitt. Schweiz. ent. Ges., 71, 285-342.

Ravizza C. \& Vinçon G. 2003. - Leuctra queyrassiana orsiera, a new subspecies of Leuctra from the Cottian Alps, Italy (Plecoptera, Leuctridae). Boll. Soc. ent. ital., 135, 19-23.

Ravizza-Dematteis E. \& Ravizza C. 1994. - Altitudinal zonation and coenotic patterns of Plecoptera in a northern Apennine stream (Plecoptera). Boll. Sot. ent. ital., 126, 51-60.

Reusch H. \& Weinzierl A. 1999. - Regionalisierte Checkliste der aus Deutschland bekannten Steinfliegenarten (Plecoptera). Lauterbornia, 37, 87-96.

Ris F. 1902. - Die schweizerischen Arten der Perliden-Gattung Nemura. Mitt. Schweiz. ent. Ges. (Lausanne) 10 (1897-1903), 378$405,432$.

Stephens J.F. 1835. - Family II. - Perlidae, Leach. In: Illustrations of British entomology; or, A synopsis of indigenous insects: containing their generic and specific distinctions with an account of their metamorphoses, etc., Baldwin \& Cradock, 6, 134-145.

Theischinger G. 1976. - Bestätigung von Protonemura algovia und Erstnachweiss von Protonemura montana für Österreich. Linzer Biol. Beitr., 8, 389-392.

Tierno de Figueroa J. M., Sanchez-Ortega A., Membiela Iglesia P. \& Luzon-Ortega J. M. 2003. - Fauna Iberica, Plecoptera, Mus. Nac. Cienc. Nat., Cons., Sup. Invest. Cient. (Madrid), 22, 1-404. 
Verneaux J. 1973. - Cours d'eau de Franche-Comté (massif du Jura). Recherches écologiques sur le réseau hydrographique du Doubs. Essai de biotypologie. Thèse. Ann. Sci. Uni. Besançon (3), zool., fasc., 9, $260 \mathrm{pp}$.

Vinçon G. 1987. - Etude hydrobiologique de la Vallée d'Ossau (Pyrénées-Atlantiques). II. Le milieu et la structure du peuplement benthique. Ann. Limnol., 23, 225-243.

Vinçon G. 1996. - Les Plécoptères des Alpes françaises. Mitt. Schweiz. ent. Ges., 69, 61-75

Vinçon G. \& Pardo I. 2004. - The Stoneflies (Plecoptera, Insecta) of the northwestern Iberian Peninsula. Ann. Limnol., Int. J. Lim. 40, 43-62.

Vinçon G. \& Ravizza C. 1998. - Three new Protonemura species from the Cordillera Cantabrica, Spain (Plecoptera, Nemouridae). Nouv. Revue Ent., 15, 249-255.

Vinçon G. \& Ravizza C. 2000. - New micropterous micro-endemic Leuctra species and subspecies from the Spanish Cordillera Cantabrica (Plecoptera Leuctridae). Bol. Soc. ent. Ital., 132, 195-203.
Vinçon G. \& Ravizza C. 2001. - Leuctridae (Plecoptera) of the Pyrenees. Ann. Limnol., 37, 293-322.

Vinçon G. \& Sanchez-Ortega A. 2002. - The genus Capnioneura in the Iberian Peninsula and the Pyrenees, with the description of $C$. narcea sp. n. (Plecoptera, Capniidae). Nouv. Revue Ent., 19, 7381.

Vinçon G. \& Sivec I. 2001. - Contribution of the knowledge of Turkish Leuctridae (Plecoptera). Nouv. Revue Ent., 18, 259-285.

Vinçon G. \& Zhiltzova L. 2004. - The genus Protonemura in Turkey (Plecoptera, Nemouridae). Nouv. Revue Ent., 21, 171-195.

Zwick P. 1971. - Die Plecopteren Pictets und Burmeisters mit Angaben über weitere Arten (Insecta). Rev. Suisse Zool., 78, 1123 1194.

Zwick P. 1973. - Insecta : Plecoptera Phylogenetisches System und Katalog. Das Tierreich 94, 32, 1-XXXII, 1-465.

Zwick P. \& Vinçon G. 1993. - Contribution to the knowledge of Pyrenean stoneflies (Insecta: Plecoptera). Ann. Limnol., 29, 47-57. 